Universidade de Brasília - UnB

FACULDADE DE ECONOMIA, ADMINISTRAÇÃO, CONTABILIDADE E CIÊNCIA DA INFORMAÇÃO E DOCUMENTAÇÃO - FACE

PROGRAMA DE PÓS-GRADUAÇÃO EM ADMINISTRAÇÃO - PPGA

CURSO DE ESPECIALIZAÇÃO EM ORÇAMENTO E FINANÇAS

PATRÍCIA RAMOS SILVA FERNANDES

CAUSAS DE DESMOTIVAÇÃO NO TRABALHO EM UMA EMPRESA PÚBLICA FEDERAL 
PATRÍCIA RAMOS SILVA FERNANDES

\section{CAUSAS DE DESMOTIVAÇÃO NO TRABALHO EM UMA EMPRESA PÚBLICA FEDERAL}

Projeto de Monografia apresentada ao Programa de Pós-Graduação em Administração (PPGA) da Faculdade de Economia, Administração, Contabilidade e Ciência da Informação e Documentação (FACE), da Universidade de Brasília, como requisito parcial à obtenção do grau de Especialista em Orçamento e Finanças.

Orientador: Prof. Dr. Marcus Vinícius Soares Siqueira.

Brasília - DF 
A Deolina e Francisco Ramos A Wilian e Heloá Fernanda 


\section{AGRADECIMENTOS}

A Santíssima Trindade, por ter me confiado a vida.

A Nossa Senhora, pelo exemplo de esperança.

Aos meus padrinhos celestiais, pela incansável intercessão.

Aos meus pais, pela educação e exemplos de bom caráter.

Ao meu esposo, pela paciência e compreensão.

A minha amada filha, por existir.

Ao futuro filho ou filha, por trazer mais amor a nossas vidas.

Ao professor Marcus Vinícius Soares Siqueira, pela paciência e conhecimentos repassados a nós alunos.

À professora Maria de Fátima Bruno Faria, pela atenção e dedicação.

Às amigas Verônica, Janaína e Gorete, pelo carinho e contribuição.

Às chefes Leide e Ivana, pela compreensão nos momentos de ausência.

A equipe GLACO - Carla, Terezinha, Leandro, Eduardo e Gerson pelo apoio.

A todos os colegas do SERPRO, em especial aos participantes das entrevistas, pela colaboração. 


\section{Resumo}

Este trabalho pretende abordar um assunto que é de extrema importância para gestão pública moderna: motivação dos seres humanos em seu ambiente de trabalho. Para tanto, propõe-se enfocar o tema e entender a percepção dos trabalhadores sobre o conceito de motivação. $\mathrm{O}$ estudo foi realizado dentro de uma Empresa Pública Federal Brasileira, com os empregados do quadro efetivo da organização. Sabe-se que motivação é a força capaz de mover o indivíduo à ação, provocando no mesmo uma mobilização para iniciar e manter-se focado num objetivo ou meta, com dinâmica e persistência no desempenho das suas ações, dando menos relevância aos obstáculos e priorizando o sucesso na tarefa (ROBBINS, 2002). Pretende-se, portanto, discutir o processo de motivação realizado pela empresa, diante de um contexto organizacional que traz consigo a falta de contratação de empregados, por meio de concurso público, por cerca de 20 (vinte) anos. Este intervalo acentuado de falta de contratação, gerou pontos extremos em referência ao tempo de serviço dos empregados. Houve o enfraquecimento do estado motivacional de cada indivíduo, em virtude da rivalidade surgida entre "antigos" empregados, os quais representam a maioria e possuem mais de 20 (vinte) anos de tempo de serviço, e "novos” empregados, minoria com no máximo 4 (quatro) anos de serviço. O estudo também trará, dentre outros objetivos, a influência da motivação sobre as atitudes das pessoas e sobre os resultados para a empresa. São apresentados conceitos, alguns aspectos das teorias motivacionais desenvolvidas ao longo do tempo, motivos que podem causar a desmotivação. Em face do estudo, verifica-se a importante missão dos gestores em criar condições e métodos organizacionais que compatibilizem os objetivos individuais com os organizacionais, alcançando a auto-valorização dos colaboradores, gerando nestes uma força que os conduza a atitudes de realização dos objetivos organizacionais em sintonia com seus próprios objetivos individuais.

Palavras-chave: motivação; empresa; organização; pública. 


\section{SUMÁRIO}

1 - INTRODUÇÃO.

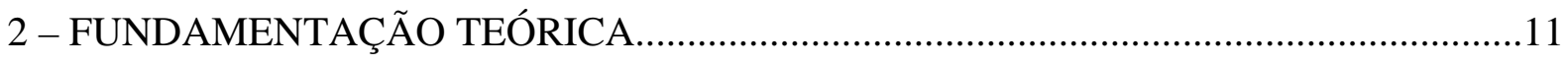

2.1 - Comportamento Humano ................................................................................11

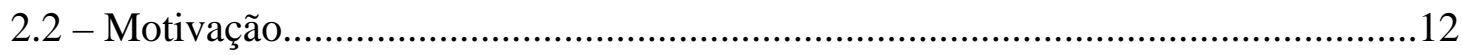

2.3 - Fatores Motivadores para o Trabalho ..............................................................13

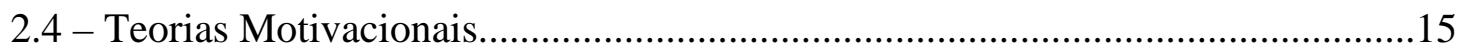

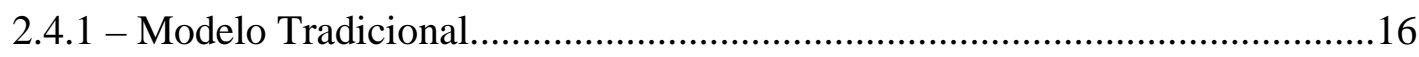

2.4.2 - Modelo das Relações Humanas.................................................................17

2.4.3 - A Hierarquia das Necessidades Humanas de Maslow.................................18

2.4.4 - Modelo dos Recursos Humanos................................................................20

2.4.5 - Teoria dos Dois Fatores de Herzberg .........................................................21

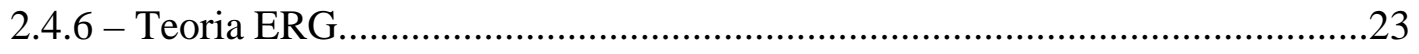

2.4.7 - Teoria das Necessidades de McClelland......................................................24

2.4.8 - Teoria da Avaliação Cognitiva..................................................................25

2.4.9 - Teoria da Fixação de Objetivos................................................................25

2.4.10 - Teoria da Eqüidade............................................................................26

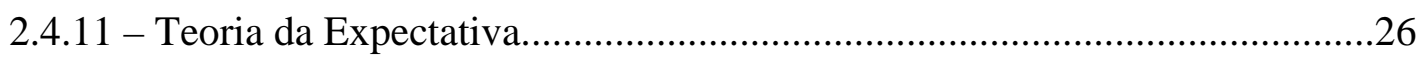

2.5 - Satisfação/Insatisfação com o Trabalho.............................................................28

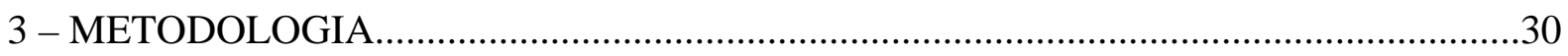

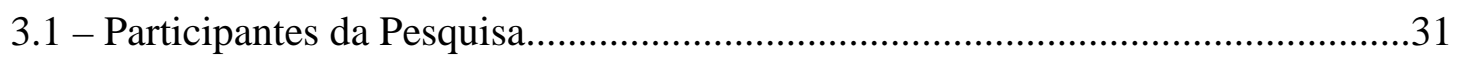

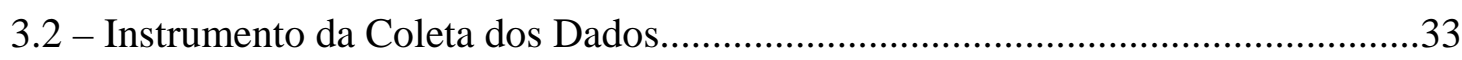

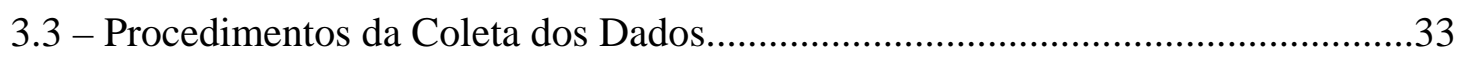

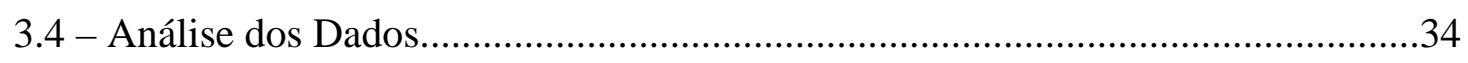

4 - RESULTADO E DISCUSSÃO DOS RESULTADOS.....................................................36

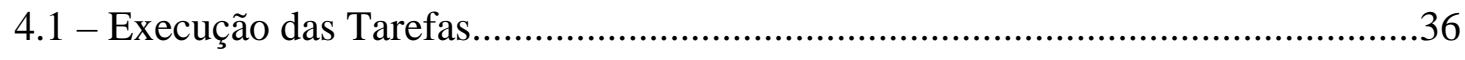

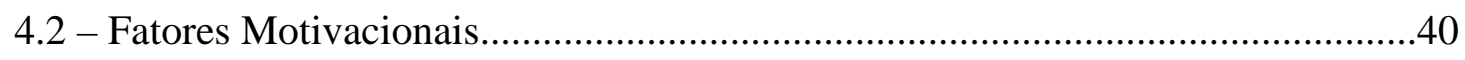

4.3 - Responsabilidades da organização sobre a motivação........................................42

4.4 - Gestão da motivação........................................................................................45

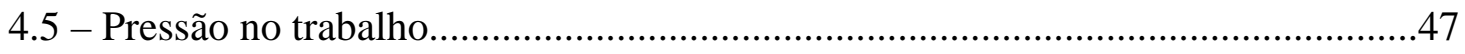


4.6 - Diversidade na execução das tarefas..................................................................48

4.7 - Flexibilidade na execução das tarefas..............................................................49

4.8 - Percepção das empregados sobre o motivação do quadro funcional....................50

4.9 - Ações e omissões da empresa que desmotivam.....................................................55

4.10 - Necessidades de mudanças institucionais..........................................................56

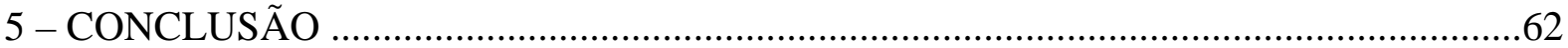

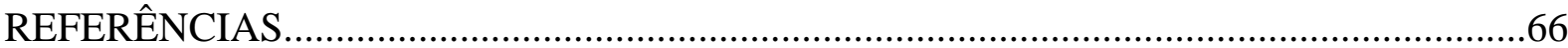




\section{Introdução}

O tema motivação no trabalho vem sendo muito discutido dentro das organizações. No setor público a questão da motivação está ligada às transformações dos últimos vinte anos e ao esquecimento de certas especificidade desse tipo de atividade (CHANLAT, 2002).

Bergamini (2008) explica e enfatiza que motivação está no centro dos problemas das organizações e que depende do significado que cada pessoa atribui a ela. A organização deverá ter a sensatez de perceber que as pessoas agem em busca de um determinado objetivo por motivos diferentes, pois o homem é único e sem réplica no universo. O comportamento dos empregados deverá ser estudado de forma específica e individual. A autora enfatiza que as empresas não têm encontrado estratégias adequadas que possam responder às necessidades de continuar atraindo, desenvolvendo e recompensando sua força de trabalho, por isso faz-se necessário procurar a compreensão dos fatores motivacionais de maneira específica e com foco em fatores intrínsecos.

Segundo Vergas (apud FIORELLI, 2004, p. 118) motivação é uma força, uma energia que nos impulsiona na direção de alguma coisa que nasce de nossas necessidades interiores. Acredita-se que quando ela acontece as pessoas tornam-se mais produtivas, atuam com maior satisfação e produzem efeitos multiplicadores. As empresas, com a intenção de obter maior produtividade e acreditando ser a maneira certa de motivar seus empregados, investem em planos e estratégias motivacionais. Estabelecem ações que consideram de seu ponto de vista eficazes para beneficiar o desempenho do empregado, tais como: lazer após o trabalho, incentivos a práticas de esportes, ginástica laboral, cinema no intervalo do almoço, possibilidade do empregado se associar a um clube. Enfim, promovem ações extrínsecas.

No serviço público as estratégias utilizadas não se diferem muito. Sabe-se que os serviços públicos representam hoje um papel determinante em todos os países industrializados, principalmente nos setores de saúde, educação, cultura, serviços sociais cumprindo ao Estado o desenvolvimento dessas funções na vida coletiva (FRÉMEAUX, 2001 apud CHANLAT, 2002, p. 1). Para que esses serviços sejam bem desenvolvidos o Governo Brasileiro contrata empregados/servidores e procura oferecer certos benefícios, como segurança no trabalho, estabilidade no emprego, remuneração maior ao se comparar com a iniciativa privada. No entanto, ainda encontramos trabalhadores desolados com as atividades que realizam. Para as organizações governamentais, as causas dessa desolação são as 
mudanças tecnológicas, políticas e mundiais que provocaram um sentimento de apática e desinteresse do trabalhador. Esse desinteresse forçou as organizações a buscarem soluções para minimizar o problema, tentando levar as pessoas, no caso os trabalhadores, a fazerem o que as organizações esperam delas, ou seja, controlá-las (KOHN, 1998 apud BERGAMINI, 2008, p. 45).

A organização acredita que a forma mais rápida de se obter do trabalhador aquilo que deseja é oferecendo bens materiais. Para Kohn:

Os administradores também parecem supor que máquina e trabalhadores são semelhantes pelo fato de ambos serem normalmente agentes passivos que devem ser estimulados por controle a fim de entrarem em ação. No caso das máquinas, liga-se a eletricidade. No caso dos trabalhadores, o dinheiro toma lugar da eletricidade. (KOHN, 1998 apud BERGAMINI, 2008, p. 45)

Kohn nos mostra que o objetivo da organização é motivar o trabalhador, ou melhor, condicionar o trabalhador a agir de acordo com o pensamento da organização.

É notório no Brasil que a maior parte do dia de um cidadão é dedicada ao seu trabalho. Na maioria dos casos são no mínimo 8 (oito) horas dentro de uma organização. Muitas vezes perguntamos o nome da pessoa e ela se identifica dizendo: sou fulano de tal, diretor disso, chefe daquilo. Enfim, o sobrenome da pessoa parece ser o cargo, a organização para a qual trabalha. Com isso verificamos que o trabalho constitui um elemento central de identidade para o homem (RIFKIN, 19997 apud CHANLAT, 2002, p. 4). Este excesso de valorização, ao ponto de defini-lo como sua identidade, resultou em mais um elemento de coerção sobre os indivíduos.

Se o trabalho representa uma identidade para o indivíduo, verifica-se que os fatores de motivação no trabalho dependem do contexto organizacional e social em que é realizado o trabalho, de como o corpo gerencial se relaciona com seus subordinados, quais são as ações das empresas voltadas para os aspectos motivacionais de seus empregados. Nesse contexto, os fatores motivacionais passam a envolver o ambiente como um todo, produzindo alterações comportamentais que se refletem na realização das atividades diárias. Por essa razão, será importante compreender neste trabalho os fatores que provocam e sustentam um comportamento motivado no trabalho.

Assim, o presente estudo tem por finalidade entender e aprofundar o tema motivação nas organizações, com foco voltado para o trabalhador de uma empresa pública federal, aqui denominada com o nome fictício de Empresa Atitude.

A Empresa Atitude tem por atividade principal à área de tecnologia da informação e comunicação. Sua missão é prover e integrar soluções em Tecnologia da Informação e 
Comunicações para o êxito da gestão das finanças públicas e da governança do Estado, em benefício da sociedade. Desenvolve soluções para o controle e transparência sobre a receita e os gastos públicos e possui cerca de 10.000 profissionais lotados em todo o território nacional. Por ser uma empresa de tecnologia e desenvolvimento de programas para o governo, com alto grau de segurança, o principal instrumento de trabalho é a força humana, ou seja, o crescimento, o desenvolvimento com soluções criativas e a continuidade da empresa estão ligados ao comportamento de seus empregados. O desempenho de cada componente da organização irá refletir nos resultados que a empresa deseja alcançar. Portanto, presumi-se que o projeto estratégico da Empresa Atitude deverá contemplar o comportamento de seu corpo funcional, com o objetivo de promover a manutenção da organização.

Sabe-se que a organização é formada por um grupo de indivíduos associados com um objetivo comum, composta de estrutura física, tecnológica e pessoas, ou seja, é um sistema formado por pessoas, recursos financeiros, recursos materiais, atuando de forma conjunta para o alcance de objetivos. De acordo com Robbins (2002) para que uma organização possa existir, ela deve atender aos seguintes pré-requisitos: existirem pessoas aptas a se comunicarem; atuarem de forma conjunta; e atingirem um objetivo comum. Com essas definições, confirma-se que a manutenção de uma organização está ligada ao comportamento de seus colaboradores.

Se a sustentabilidade das organizações depende do comportamento profissional do empregado, há necessidade de saber quais são os sentimentos dos empregados em relação à empresa, ao trabalho, ao desenvolvimento das tarefas. O trabalhador pode gostar do que faz e continuar insatisfeito com o serviço, sem formalizar à empresa esta situação. Não encontra dentro das empresas setores que possam ouvir, entender e solucionar suas frustrações. Continuam naquele serviço por medo de não encontrar outro, ou de encontrar um pior, ou mesmo porque se sentem incapacitados para a dinâmica do mercado atual de trabalho.

Portanto, se trabalhador e organização estão correlacionados, esta ligação vem a confirmar a necessidade das organizações acrescentarem aos seus planejamentos estratégicos de alcançar maior rentabilidade, eficácia e agilidade em seus serviços, medidas que possam incentivar a participação de seus colaboradores a agirem de maneira espontânea e de forma consciente, sem incentivos condicionantes. As empresas precisam investir em qualidade de trabalho e individualizar o tratamento de seus funcionários (BERGAMINI, 2008). Não somente investirem nas habilidades profissionais, oferecendo cursos, graduações, certificados. Um empregado poderá ter todos os títulos possíveis de sua carreira e, no entanto estar 
desmotivado, sem vontade de desenvolver suas tarefas. Os males de uma relação abalada entre funcionário e empresa podem gerar um ambiente de fofoca, de desmotivação, de desgosto pelo trabalho, de indisciplina, de falta de vontade para a execução das tarefas, paralisia para adquirir novos conhecimentos.

Assim, pretende-se como tema central deste estudo e objetivo geral, analisar se os empregados da Empresa Atitude estão desmotivados na execução do seu trabalho e no alcance dos resultados organizacionais, identificando as possíveis causas que podem levar ou levaram estes empregados a se sentirem desmotivados na realização de suas tarefas.

Já os objetivos específicos poderão contribuir para:

- Saber se os empregados da Empresa Atitude consideram-se pessoas motivadas ou não;

- Conhecer as ações que eles esperam que a empresa desenvolva para motivá-los;

- Identificar os fatores que os levaram a se tornar trabalhadores desmotivados;

- Identificar as experiências profissionais consideradas negativas;

- Verificar o momento em que houve o desestímulo para o alcance de um determinado objetivo;

- Entender o que pode gerar um elevado grau de rotatividade de empregados na empresa;

- Compreender o que representa a organização para o trabalhador.

Este estudo pretende também verificar quais são as práticas desenvolvidas pela Empresa Atitude que estão voltadas para influenciar o comportamento de seus empregados e entender se as práticas empregadas são eficazes, se estão atingindo a finalidade para qual são executadas. Contribuirá ainda para esclarecer se há orientações direcionadas para ajudar o empregado a determinar qual o objetivo que ele deseja alcançar. Com isso, espera-se que fique claro se a empresa tem interesse em conhecer os objetivos dos empregados, se esses objetivos estão de acordo com que a empresa espera do empregado, ou seja, se há um tratamento individualizado para tentar conhecer o empregado a nível profissional.

A estruturação deste estudo se iniciará com uma parte introdutória, onde é contextualizado o problema e são descritos os objetivos. Após, teremos a fundamentação teórica acerca do comportamento humano, modelo e comportamento organizacional, conceito de motivação, alguns fatores motivadores para o trabalho, teorias motivacionais e satisfação versus insatisfação no trabalho. Na terceira parte será descrita a metodologia utilizada para investigar as causas de desmotivação dos empregados da Empresa Atitude. Em seguida será realizada a análise dos dados coletados, apresentando os resultados obtidos, sua discussão e conclusão. 


\section{2 - Fundamentação Teórica}

\section{1 - Comportamento Humano}

Estudos voltados para comportamento humano tem como objetivo ajudar a entender as ações realizadas pelas pessoas em determinadas situações. A riqueza da diversidade no comportamento humano é o principal ponto a ser considerado. Os indivíduos desde seus códigos genéticos, passando pela vida intra-uterina até a fase da vida adulta, passam por diferentes estímulos e vivências, tudo isso contribui para a formação da identidade, formando personalidades sem réplicas. A partir do momento, que há compreensão de que a personalidade do ser humano é única, já se pode supor que um único estímulo, terá resultados comportamentais diferentes nas pessoas ( BERGAMINI, 2008).

O presente estudo abordará estímulos voltados para motivar pessoas no contexto de uma organização, ou seja, dentro do ambiente de trabalho. Como motivação está estritamente ligado a comportamento, notamos que uma simples observação das pessoas mostra o quanto são diferentes umas das outras e por isso, qualquer gestão tenderá ao fracasso, se dirigi-las como se fossem iguais ( BERGAMINI, 2008).

Bergamini ( 2008) ressalta que quanto mais o tempo passa, mais vivências o indivíduo levará para compor sua identidade. Para ela, se houver vontade própria o indivíduo poderá modificar superficialmente seu comportamento, sem modificá-lo ao extremo, e com isso, alterar seu modo de ser dentro da organização, como por exemplo, o tímido torna-se sociável, o lento mais afobado.

A autora ressalta que tentar interferir no comportamento humano, especificamente na personalidade do indivíduo, pode ser uma estratégia fadada ao fracasso. As pessoas tem sua própria orientação do que irá motivá-la a mudar seu comportamento. A organização ao pedir que a pessoa mude suas características pessoais, tais como tornar-se uma pessoa mais extrovertido, racional, poderá contribuir para que ela se sinta invadida e desmotivada. É indispensável descobrir o que realmente atrai o outro motivacionalmente e que esses motivos são diferentes do que se está buscando pessoalmente para si. Por isso, para entender o conceito de motivação, a organização terá que conhecer como o comportamento humano é iniciado, persiste e termina, adotando um enfoque descritivo, enumerativo desse 
comportamento. Assim, a forma mais natural de se entender a motivação humana é individualizar as pessoas, levando em consideração sua vida particular.

Bergamini acrescenta que mesmo com a observação do comportamento, a organização não terá parâmetros para elaborar mecanismos que possam motivar as pessoas. Pois, mesmo observando-os, os seres humanos expressam motivos diferentes por meio de atos semelhantes, possuem diferenças individuais e culturais entre si e trazem consigo aquilo que tem o potencial de impulsionar a buscarem determinados objetivos. De acordo com a autora para liberar o potencial motivacional é necessário dar "às pessoas liberdade de escolher que tipo de ação empreender, respeitando as próprias fontes interiores de necessidades, e descartando-se, assim, todo o tipo de controle extrínseco que possa ser imposto pelo meio ambiente”.

Será dentro do Modelo Organizacional de cada instituição que se compreenderá o sentido da palavra motivação para os empregados. É por meio dessa investigação que a organização visualizará o impacto que indivíduos, grupos e a estrutura têm sobre o comportamento dentro das organizações, estudará o que as pessoas fazem na organização e como o comportamento dessas pessoas afeta o desempenho da empresa. Entenderá especificamente as situações relacionadas com o emprego, com as funções desenvolvidas, com o absenteísmo, com a rotatividade, com a produtividade, com o desempenho humano e com a administração ( ROBBINS, 2002).

Segundo Robbins quando a preocupação com a estrutura se desloca para a preocupação com os processos e com a dinâmica organizacionais, passa-se a abordar o comportamento organizacional. O comportamento organizacional se fundamenta no comportamento individual das pessoas e para motivar as pessoas é necessário entendê-las individualmente.

\section{2 - Motivação}

O conceito de motivação é extremamente importante para compreender os mecanismos que movimentam as pessoas na busca de seus objetivos. A motivação é caracterizada por aquilo que faz as pessoas se sentirem estimuladas a buscarem um determinado objetivo, seja ele geral ou específico. 
A origem etimológica do termo motivação explica que deriva originalmente da palavra latina “movere", que significa mover, indicando um estado de despertar do organismo, da vontade, do ânimo, de dinâmica ou ação. Para que haja esse despertar o indivíduo precisa identificar o motivo, o que o move em direção a determinado objetivo ( BERGAMINI, 2008).

Segundo Robbins (2002, p. 151) motivação é o "resultado da interação entre o indivíduo e a situação". Relata que para formar o conceito de motivação, devemos ter em mente que o nível de motivação varia tanto entre indivíduos quanto para indivíduos em tempos diferentes. Assim, motivação é definida como a vontade de empregar altos níveis de esforço em direção a metas organizacionais, condicionada pela capacidade do esforço de satisfazer alguma necessidade do indivíduo. O estudo acrescenta que a motivação existe dentro das pessoas e se dinamiza através das necessidades humanas. Todas as pessoas têm suas necessidades próprias, que podem ser chamadas de desejos, aspirações, objetivos individuais ou motivos. Robbins ainda caracteriza que os três elementos-chave da definição de motivação são as palavras: intensidade, direção e persistência.

Temos ainda o seguinte conceito:

Motivação é uma força, uma energia que nos impulsiona na direção de alguma coisa, ela é absolutamente intrínseca, isto é, está dentro de nós, nasce das necessidades interiores do indivíduo, o que vem de fora é estimulo, incentivo e provoca a motivação. (VERGARA, 2000, p.42)

Para Bergamini (2009) a verdadeira motivação humana é representada por uma necessidade nitidamente de caráter interior e seus determinantes residem no interior de cada pessoa. A autora diz que a personalidade, as predisposições emocionais, a educação, a cultura, as crenças, tudo pode interferir no comportamento do homem. A força despendida em cada ação para se alcançar um determinado objetivo, depende do significado e do valor atribuído por ela àquele objetivo.

\section{3 - Fatores Motivadores para o Trabalho}

Um estudo realizado por Chanlat ( 2002) descreve que mesmo sendo variados os empregos públicos ( professor, enfermeira, carteiro, policial) e com tarefas diferentes, o que há de comum entre eles é a ligação ao setor público. O autor enriquece o estudo descrevendo que existem cinco fatores que fazem com que um trabalho seja interessante e que estes fatores 
produzem conseqüências sobre a motivação para o trabalho, sejam eles: uma boa carga de trabalho, um bom grau de autonomia, um forte reconhecimento do que se faz, amparo social adequado e comportamento ético.

No entanto, as práticas das empresas privadas trazidas para o setor público, acarretaram mudanças nos cinco fatores descritos pelo autor, sejam elas:

- Primeiro: aumento de carga de trabalho. Devido a redução de pessoal, da busca por desempenho e produtividade, da pressão por parte dos usuários dos serviços oferecidos.

- Segundo: redução da autonomia. Mesmo com apelo para se aumentar a responsabilidade e a imputabilidade dos empregados, existem as contradições e as incoerências com a realidade, por causa do excesso de hierarquia e controle do atos.

- Terceiro: falta de reconhecimento. Os funcionários sofrem com o discurso de falta de eficiência, pouca produtividade e até sua verdadeira utilidade. Dejours ( 1990 apud CHANLAT, 2002, p. 5) explica que o reconhecimento está no âmago do prazer e do sofrimento no trabalho.

- Quarto: fragmentação do apoio social oferecido pelo colegas, superiores, subordinados ou usuários do serviço. Em virtude das práticas de gestão pessoal vinda da iniciativa privada, como contratação de pessoal por tempo determinado, terceirização, rompeuse uma característica fundamental do serviço público: segurança no emprego. A segurança é a condição fundamental para se manter a neutralidade e a independência do funcionário.

- Quinto: enfraquecimento do comportamento ético no serviço público. A ação do servidor público deve ser voltada para o bem comum, interesse geral e guiada pela ética. No serviço público há necessidade de despersonalizar a função administrativa, ou seja, distanciar a pessoa do posto ocupado, deixando de lado as posições pessoais. Por isso, as práticas empresariais de gestão podem ser uma ameaça a essa separação, uma vez que o funcionário terá que obedecer as exigências do cliente, do chefe imediato. O autor relata que "a imparcialidade, o tratamento igualitário e o interesse social correm o risco de desaparecer a longo prazo em benefício de mecanismos cada vez mais mercantis.”

Em virtude das conclusões que Chanlat descreveu e considerando o papel da ética como forte fator motivacional, ele defende a seguinte idéia de que "a problemática da motivação no trabalho dos empregados do serviço público não se baseia somente sobre 
elementos comuns a todo trabalho profissional, ela deve levar em conta a ética particular ligada à ação pública” ( CHANLAT, 2002, p. 6).

Para confirmar sua idéia a cerca de motivação, Chanlat relembra o caso da catástrofe do World Trade Center, onde policiais e bombeiros deram sua própria vida levando o socorro a seus concidadãos. Por isso, o autor menciona que o orgulho de pertencer a uma categoria que se define pelo serviço dos outros é um poderoso fator de motivação quando realmente vivido. Portanto, as práticas de gestão do setor privado podem afetar o que fundamenta a ação de utilidade pública no que ela tem de mais específico: a ética do interesse geral e a defesa da justiça.

O autor também frisa a questão da burocracia, relatando que só há desenvolvimento equilibrado com burocracia competente, íntegra, independente e dedicada à causa do bem comum. Conclui mencionado que os reformadores do setor público devem notar que “ a solidariedade está na base do desenvolvimento social e do funcionamento eficaz da economia de um país”. Caso não trabalhem voltados para a solidariedade, verão a diminuição da qualidade dos serviços e uma desmobilização de seu pessoal ( PETRELLA, 1996 apud CHANLAT, 2002, p. 7).

\section{4 - Teorias Motivacionais}

As teorias que primeiro estudaram a motivação procuravam encontrar um único modelo para todos os tipos de empregados e para qualquer tipo de organização. Apesar desse ponto comum, cada modelo tinha o seu posicionamento em relação aos seres humanos. As diversas teorias não se anulam umas às outras, elas se complementam para propor uma visão mais abrangente do ser humano. Apesar das diferentes interpretações, com o passar do tempo e a modernização do trabalho, as teorias se mostraram deficientes ao focar apenas um fator motivacional para explicar qual a melhor filosofia a ser adotada para administrar pessoas. Portanto, não existe uma única teoria que seja capaz de desvendar todas as características que possam motivar o ser humano (BERGAMINI, 2008). 


\subsection{1 - Modelo Tradicional}

Antes da Revolução Industrial acreditavam que os principais instrumentos para se motivar o ser humano era, em primeiro lugar, o uso de ameaças e punições, gerando um ambiente de medo, e em segundo lugar, as promessas de recompensas e favores especiais àqueles que mostrassem maior desempenho. Já na época da Revolução Industrial, os estudiosos de Recursos Humanos foram solicitados a criarem planos salariais e benefícios extras que pudessem motivar as pessoas a maximar a produção e, consequentemente, o lucro. Surgem pesquisadores propondo a necessidade de buscar o conforto físico e a segurança no trabalho, a busca da segurança de não perder a fonte de sustento, garantindo o emprego por mais tempo (BERGAMINI, 2008).

Em meio a esse contexto surge o que se denomina de Modelo Tradicional. Segundo Bergamini ( 2008), o Modelo Tradicional, com Frederick Taylor, principal contribuidor do que se conhece por Administração Científica de Taylor, usava o seguinte raciocínio: determinava a maneira mais eficiente de realizar tarefas repetitivas, tornando as operações no trabalho mais simples. A partir daí, procuravam motivar os empregados por meio de incentivos salariais, relacionados à produtividade de cada um. Quanto maior a produtividade, maiores os ganhos salariais. A visão que se tinha dos empregados nesse modelo é de que eram preguiçosos e de que somente o dinheiro poderiam motivá-los.

De início, o modelo deu certo. Mas, os trabalhadores logo perceberam que estavam arriscando sua própria sobrevivência nas organizações às quais pertenciam. Pois, num futuro próximo, isso iria requerer um menor número de trabalhadores para que fosse atingido o mesmo resultado. Para tanto, os trabalhadores adotaram um ritmo de trabalho mais lento, com a intenção de diminuir a produtividade para garantir a sua permanência. Os trabalhadores conscientizaram-se de que o mais importante, naquele momento, era lutar por estabilidade no emprego, ao invés de contentar-se com aumentos salariais incoerentes com a realidade em que viviam (ROBBINS, 2002).

Assim, o modelo de Taylor tem como principal argumento que a forma de motivar as pessoas é oferecendo recompensas saltarias, pois, pagando-se bem os problemas dos trabalhadores estariam solucionados. Com base nestes princípios acreditavam que o 
comportamento humano poderia ser planejado, modelado e finalmente mudado, ou seja, motivação e condicionamento seriam a mesma coisa. Este pensamento vem sendo utilizado até nos dias de hoje, apesar de ser criticado por vários autores e de ter dado errado na época. Denomina-se esse tipo de motivação como extrínseco, não sendo considerado como responsável pela verdadeira motivação e sim, como uma forma de controle comportamental ( DECI, 1998 apud BERGAMINI, 2008, p. 13).

É fato que muitas vezes, uma pessoa sente-se levada a fazer algo para evitar uma punição ou para conquistar uma recompensa. Entretanto, em ambos os casos, a iniciativa para a realização da tarefa não partiu da própria pessoa, mas de um terceiro, que a estimulou de alguma forma para que ela se movimentasse em direção ao objetivo pretendido. A pessoa não teria caminhado em direção ao objetivo caso não houvesse a punição ou a recompensa. Bergamini lembra que as pessoas também podem agir levadas por um impulso interno, por uma necessidade interior. Neste caso, existe vontade própria para alcançar o objetivo, existe motivação, que pode ser transformada em movimento permanente por meio da doutrinação. Para a autora, é isso que as organizações produtivas devem buscar.

\subsection{2 - Modelo das Relações Humanas}

Bergamini ( 2008) descreve que enquanto o modelo tradicional procurava motivar os trabalhadores para tarefas repetitivas, o Modelo de Relações Humanas buscava justamente o contrário: mostrar que esse tipo de atividade desmotivava cada vez mais o empregado e que só através de contatos sociais a motivação seria fortalecida, procurando valorizar a pessoa na sua totalidade. O objetivo da motivação, nesse caso, era dar prioridade às necessidades sociais do empregado, tornando-o agente de transformação. Nesse tipo de modelo, criam-se oportunidades para que os empregados passem a agir, pautando-se em grupos informais de trabalho e os administradores tomem consciência do poder dos grupos informais na organização. Esse grau de liberdade dos empregados implicava também que os mesmos aceitassem a autoridade que lhes era imposta pelos administradores. Esse modelo representou um avanço em relação ao modelo tradicional, mas foi superado pelo modelo dos recursos humanos. O teórico mais importante desse modelo foi Elton Mayo. 


\subsection{3 - A Hierarquia das Necessidades Humanas de Maslow}

As diferentes necessidades que coexistem no interior das pessoas são chamadas de desejos ou expectativas. Portanto, diz-se que motivação e necessidades são sinônimos, ou seja, quanto maior a necessidade não atendida, maior à motivação. Assim, a satisfação passa a ser considerada como oposta à motivação: quanto mais satisfeita uma necessidade, menos ela energiza o comportamento ( BERGAMINI, 2008).

Bergamini (2008) conceitua necessidade como "os motivos pelo quais cada um se põe em movimento em busca de certos fins, não podem ser observadas de maneira direta, só se consegue inferir que elas existem a partir da observação de comportamentos mais evidentes”.

Para Abraham Maslow, as pessoas possuem necessidades insatisfeitas que orientam e influenciam o comportamento. Por essa razão, fundamenta sua teoria na hierarquia das necessidades humanas. Ou seja, há uma escala de prioridade das necessidades humanas, a qual dividiu em cinco níveis: necessidades fisiológicas, de segurança, sociais, de estima e auto-realização. Essa hierarquia de necessidades pode ser visualizada como uma pirâmide de importância e de influência do comportamento humano. Na base da pirâmide estão as necessidades mais baixas e concorrentes (necessidades fisiológicas), enquanto que no topo estão as mais intelectuais e sofisticadas (necessidades de auto-realização) (ROBBINS, 2002).

As necessidades fisiológicas são as necessidades humanas de alimentação, sono e repouso, abrigo, desejo sexual e outras necessidades corporais. Quando alguma dessas necessidades não está satisfeita, ela domina a direção do comportamento. São conhecidas como biológicas ou básicas, existem para garantir a sobrevivência do indivíduo.

As necessidades de segurança, chamadas também de necessidades de estabilidade, constituem o segundo nível. Ela traz o desejo da busca da estabilidade, de proteção de qualquer perigo e surgem quando as necessidades fisiológicas estão relativamente satisfeitas. As necessidades de segurança têm grande importância no comportamento humano, uma vez que o empregado mantém uma relação de dependência com a empresa, onde ações administrativas contrárias ao direito ou decisões contraditórias provocam incerteza ou insegurança no empregado quanto à sua permanência no empregado. 
As necessidades sociais ocupam a terceira categoria na ordem piramidal de Maslow. Surgem quando as necessidades fisiológicas e de segurança estão relativamente satisfeitas. As frustrações dessas necessidades provêem da falta de adaptação social e da solidão. Quando essas necessidades encontram-se insatisfeitas, o indivíduo se torna resistente, antagônico e hostil com relação às pessoas que o cercam. Nas organizações as necessidades de reconhecimento e amor podem ser visualizadas da seguinte forma: união dos setores, não existência de fofocas invejosas, valorização verbal e não-verbal dos funcionários, comprometimento dos colegas com o negócio e as tarefas, fazer parte de equipes de trabalho, grupo e comissões.

As necessidades de estima são relacionadas com a maneira que o próprio indivíduo se vê e se examina, isto é, com auto-estima e auto-avaliação. Abrangem a autoconfiança, a autoapreciação, de status, a necessidade de aprovação social e conhecimento, de prestígio e de consideração. A satisfação dessas necessidades conduz a sentimentos de valor, força, poder, capacidade e utilidade. A sua frustração, por sua vez, podem levar ao desânimo ou a atividades compensatórias.

As necessidades de auto-realização situam-se no topo da hierarquia. São elas que levam o indivíduo a realizar seu próprio potencial (desejo de auto-desenvolvimento e autosatisfação) e a busca por criatividade contínua ao longo da vida. Se expressa por meio do impulso de a pessoa torna-se sempre mais do que é e de vir a ser tudo o que pode ser. Para Connellan ( 1994, p.51), “esta ordem mais alta de necessidades pode ser vista com maior freqüência naqueles indivíduos que agem para sua própria satisfação intrínseca, do que naqueles que executam uma ação somente porque ela satisfaz a uma das quatro necessidades mais básicas”.

Robbins (2002) descreve que a Teoria da Hierarquia de Necessidade de Maslow pressupõe os seguintes aspectos:

- Somente quando se satisfaz um nível é que surge o outro.

- Nem todas as pessoas conseguem chegar no nível mais alto e essa discrepância se deve às circunstâncias da vida.

- O comportamento do indivíduo é dominado pela satisfação das necessidades, ou seja, se a necessidade mais baixa está razoavelmente satisfeita o indivíduo procura alcançar a próxima. Mas, se a necessidade mais baixa deixa de estar satisfeita o indivíduo desloca seu comportamento para àquela necessidade.

- Cada pessoa possui mais de uma motivação. 
- Qualquer comportamento motivado expressa ou satisfaz as necessidades fundamentais.

- As frustrações são ameaças psicológicas, que produzem reações de emergência no comportamento humano.

Assim, Robbins concluiu que a Teoria da Hierárquica das Necessidades supõe que necessidades não satisfeitas geram estados desagradáveis e que empregados motivados estão em estado de tensão. Essa tensão poderá orientar as metas organizacionais. Pois, para o autor, quanto mais tensão, maior será o nível de esforço.( ROBBINS, 1999 apud BERGAMINI, 2008, p. 36). A conclusão de Robbins veio a confirmar o que Bergamini enfatiza em seus estudos, ou seja, que motivação é um "fenômeno de ordem interior que liga os seguintes elementos: tensão, impulsos, comportamento de busca, necessidade satisfeita e finalmente redução da tensão”.

\subsection{4 - Modelo dos Recursos Humanos}

Modelo voltado para maturidade profissional do trabalhador. Considera que o ser humano, por natureza, trabalha muito e é produtivo. Essa afirmação é a base para o desenvolver de teorias que venham à contradizer as teorias da Administração Científica ( BERGAMINI, 2008).

Robbins (2002, p. 153) traz Douglas McGregor como maior representante desse modelo. McGregor critica o modelo das relações humanas, “acusando-o de ser um meio artificial de ludibriar os empregados e que os modelos anteriores consideravam apenas o dinheiro ou os contatos sociais como únicos fatores de motivação dos empregados”. A partir daí, McGregor propôs duas visões distintas do ser humano: uma positiva e outra negativa, denominada Teoria X e a Teoria Y.

Douglas McGregor ressaltou a importância de um administrador esclarecer suas posições acerca da natureza do homem dentro da situação de trabalho. Se o administrador compreendesse seus subordinados, ele seria capaz de selecionar um sistema de motivação que auxiliaria a dirigir os esforços na direção da meta desejada. O autor preocupou-se em comparar dois estilos opostos e antagônicos de administrar: de um lado, um estilo baseado na 
teoria tradicional, mecanicista e pragmática (Teoria X), e, de outro, um estilo baseado nas concepções modernas a respeito do comportamento humano (Teoria Y) (ROBBINS, 2002).

A Teoria X é a concepção tradicional de administração e baseia-se em convicções errôneas e incorretas sobre o comportamento humano, como por exemplo: o homem é indolente e preguiçoso por natureza, não possui ambição, é egocêntrico, resistente às mudanças, sem autocontrole e disciplina. Essa teoria baseia-se tanto no Modelo Tradicional como no Modelo das Relações Humanas, ou seja, procura motivar os empregados ou com salários ou fazendo-os sentirem-se úteis. Em função dessas concepções reflete um estilo administrativo duro, rígido e autocrático, ou seja, soberano, absoluto e independente. Limitase a fazer as pessoas a trabalharem obedecendo padrões previamente planejados. O trabalhador é visto como um recurso ou meio de produção.

A Teoria Y baseia-se em concepções atuais e sem preconceitos a respeito da natureza humana, por exemplo: o homem não despreza o trabalho; as pessoas não são, por sua natureza, passivas ou resistentes às necessidades da empresa; as pessoas têm motivação básica e capacidade para assumir responsabilidades; o homem aprende não somente a aceitar, mas também a procurar responsabilidade; a capacidade de imaginação e de criatividade na solução de problemas empresariais é amplamente distribuída entre as pessoas. Em função dessas concepções seu estilo de administrar é mais aberto, dinâmico, democrático, pois administrar passa a ser um processo de se criar oportunidades, descobrir potenciais, retirar obstáculos, encorajar o crescimento individual e proporcionar orientação quanto aos objetivos.

McGregor defendeu que cada uma dessas orientações refletia em crenças básicas sobre a natureza do comportamento humano, as quais subseqüentemente influenciariam um gerente a adotar uma abordagem motivacional ao invés de outra. Para ele, se um trabalhador não conseguir alcançar um nível de maturidade motivacional é porque a organização da qual faz parte não o favoreceu ( BERGAMINI, 2008).

\subsection{5 - Teoria dos Dois Fatores de Herzberg}

Robbins (2002) nos traz a proposição de Frederick Herzberg, o qual elaborou a Teoria dos Dois Fatores, com o objetivo de explicar o comportamento das pessoas no ambiente de trabalho. Para ele existem dois tipos de fatores que orientam o comportamento das pessoas: 
fatores higiênicos e motivacionais. Herzberg, ao estudar a motivação, deu maior ênfase ao comportamento do homem dentro das organizações e enfatiza que o entendimento das necessidades humanas requer um estudo profundo do ambiente.

Os fatores higiênicos ou fatores de manutenção ou extrínsecos estão localizados no próprio ambiente que rodeia as pessoas e abrangem as condições dentro das quais desempenham seu trabalho. São principais fatores higiênicos: o salário, os benefícios sociais, o tipo de líder ou supervisor que as pessoas recebem, as condições físicas e ambientais de trabalho, as políticas e diretrizes da empresa, os regulamentos internos, o clima organizacional. Como essas condições são administradas pela empresa, os fatores higiênicos estão fora do controle das pessoas. Ademais, estão ligados ao ambiente periférico ou extrínseco ao indivíduo, isto é, são fatores de contexto que se situam no ambiente externo que circunda o indivíduo. De acordo com Herzberg, tradicionalmente, apenas os fatores higiênicos eram considerados na motivação dos empregados, o trabalho era visto como uma atividade desagradável e, para fazer com que as pessoas trabalhassem mais, tornava-se necessário o apelo para prêmios e incentivos salariais, liderança democrática, políticas empresariais abertas e estimuladoras, isto é, incentivavam as pessoas a trabalharem em função de recompensas (motivação positiva) ou punições (motivação negativa) ( ROBBINS, 2002).

Os fatores higiênicos têm como principal característica evitar a insatisfação dos trabalhadores. Por outro lado, tem dificuldade de elevar consistentemente a satisfação e, quando o elevam, não conseguem sustentá-lo elevado por muito tempo. Porém, quando são precários ou péssimos, os fatores higiênicos provocam a insatisfação das pessoas. Herzberg dá o nome de fatores insatisfacientes a esses fatores, devido a influência voltada para a insatisfação. O nome dado de fatores higiênicos é para enfatizar que são considerados profiláticos e preventivos, similares a remédios higiênicos, ou seja, evitam a insatisfação dos empregados, mas não provocam a satisfação. No caso dos remédios evitam a infecção, mas não provocam a saúde.

Para Bergamini (2008), não basta oferecer fatores de higiene para se obter a motivação. Atendidos os fatores periféricos está se garantindo apenas o bem estar físico das pessoas. É necessário ir além disso e oferecer as pessoas oportunidades que garantam sua chegada aos objetivos de satisfações interiores, responsáveis pela verdadeira motivação.

Os fatores motivacionais ou fatores intrínsecos são chamados assim por Herzberg porque estão relacionados com o conteúdo do cargo e com a natureza das tarefas que o indivíduo executa. Assim sendo, os fatores motivacionais estão sob o controle da pessoa, isto 
porque estão relacionados com aquilo que ela mesma faz e desempenha. Envolvem sentimentos de crescimento individual, de reconhecimento profissional e as necessidades de auto-realização. Tradicionalmente as tarefas e cargos são ordenados e definidos preocupandose, exclusivamente, com os princípios de economia e de eficiência, deixando de lado, os aspectos de desafio e de oportunidade para a criatividade individual. Com isso, perdem o significado psicológico para a pessoa que os executa, as quais passam a se desmotivar, incentivando, inclusive, a apatia, o desinteresse e a falta de sentido psicológico, já que a empresa nada mais oferece além do ambiente higiênico próprio para o trabalho.

Herzberg aborda que quando os fatores motivacionais são ótimos, eles elevam a satisfação das pessoas no trabalho. Porém, quando precários, evitam a satisfação. O autor enfatiza que os fatores motivacionais responsáveis pela satisfação profissional são totalmente distintos dos fatores responsáveis pela insatisfação profissional. A satisfação profissional está voltada para o conteúdo e atividade do cargo, se há desafio e estímulos para o desempenho. Já, a insatisfação ocorre devido ao ambiente de trabalho, ao salário, aso benefícios, ao contexto geral que envolve o cargo ( ROBBINS, 2002).

\subsection{6 - Teoria ERG}

A Teoria ERG, denominada ERC em português, tem sua origem nos estudos de Clayton Alderfer, o qual fez uma revisão na Teoria da Hierarquia das Necessidades de Maslow. Esta teoria resume os cinco níveis da Teoria de Maslow em apenas três, da seguinte forma ( ROBBINS, 2002):

- Primeiro grupo: existência (E) - equivalente às necessidades fisiológicas e de segurança de Maslow. Refere-se aos requisitos materiais básicos.

- Segundo grupo: relacionamento $(\mathrm{R})$ - correspondente às necessidades de relações pessoais e as de estima de Maslow. Refere-se ao desejo de manter importante as relações interpessoais.

- Terceiro grupo: crescimento (C) - inclui as necessidades de auto-realização (desejos de ser criativo, de prestar contribuições úteis e produtivas e de ter oportunidades de desenvolvimento pessoal). Refere-se ao desenvolvimento pessoal. 
A Teoria ERC (ERG) contrapõe a de Maslow na idéia da rigidez hierárquica, segundo a qual o ser humano segue linearmente a satisfação de suas necessidades, mudando de um nível inferior para outro superior quando o mesmo foi substancialmente satisfeito. Para Alderfer, a transferência de um nível para o outro não ocorre somente após a satisfação do nível inferior. Uma pessoa pode, por exemplo, estar registrando crescimento mesmo que as necessidades de existência ou de relacionamento não estejam satisfeitas ou todas as três categorias de necessidade podem estar operando ao mesmo tempo. A proposta de Alderfer acredita que a satisfação das necessidades não é seqüencial, mas sim simultânea, com base em dois princípios ( ROBBINS, 2002):

- Mais de uma necessidade pode funcionar ao mesmo tempo: na hipótese de uma necessidade na parte superior permanecer insatisfeita;

- Aumenta o desejo de satisfazer a uma necessidade da parte inferior.

\subsection{7 - Teoria das Necessidades de McClelland}

Segundo David McClelland existem necessidades aprendidas e socialmente adquiridas com a interação do ambiente, divididos em três categorias: realização, poder e associação. Definidas da seguinte forma ( ROBBINS, 2002):

- Necessidades de Realização: desejo de alcançar algo difícil, lutar pelo de sucesso. Para tanto, procuram domínio de tarefas complexas e superação de outras, puxam para si e assumem responsabilidades, gostam de correr riscos calculados, querem retorno concreto sobre seu desempenho, não são motivados por dinheiro em si. Os indivíduos com este tipo de necessidade pretendem, mais que obter sucesso individual, preferem trabalho com bastante responsabilidade, feedback e um grau médio de riscos.

- Necessidades de Associação: desejo de estabelecer relacionamento pessoais próximos, de evitar conflito e estabelecer fortes amizades. É uma necessidade social, de companheirismo e apoio, para desenvolvimento de relacionamentos significativos com pessoas. Preferem situações de cooperação em vez de competição. São motivados por cargos que exigem interação freqüente com colegas. Tem dificuldade em avaliar os subordinados de forma objetiva, as pessoas são mais importantes que a produção. 
- Necessidades de Poder: desejo de influenciar ou controlar outros, ser responsável por outros e ter autoridade sobre outros. Necessidade de dominar, influenciar ou controlar pessoas. Procuram por posições de liderança. Possuem uma elevada tendência para o poder, pois está associada a atividades competitivas, bem como ao interesse de obter e manter posições de prestígio e reputação.

Segundo McClelland todas as pessoas possuem um pouco destas necessidades, em graus diferentes, contudo uma será característica da pessoa em causa.

\subsection{8 - Teoria da Avaliação Cognitiva}

Segundo a "Teoria da Avaliação Cognitiva”, quando uma recompensa externa é dada porque o indivíduo realizou uma tarefa interessante, isto causa uma queda no interesse pela tarefa em si, ponderando que no caso de tarefas desagradáveis o pagamento externo parece aumentar a motivação intrínseca. A explicação popular é que a pessoa experimenta uma perda de controle sobre o seu próprio comportamento, diminuindo a motivação intrínseca que existia. Para que o pagamento e outras recompensas externas funcionem como motivadores eficazes, eles precisam ser contingentes ao desempenho do indivíduo. Mas, mesmo assim, isto diminuiria a satisfação interna que o indivíduo consegue ao realizar seu trabalho ( ROBBINS, 2002).

\subsection{9 - Teoria da Fixação de Objetivos}

Segundo Robbins (2002), a Teoria da Fixação de Objetivos, proposta por Edwin Locke, relata que a intenção de lutar por um objetivo é a maior fonte de motivação do trabalho. Ou seja, um objetivo diz ao funcionário o que precisa ser feito e quanto esforço terá de ser despendido em seu alcance. Se fatores como a capacitação e a aceitação do objetivo forem mantidos constantes, também podemos afirmar que, quanto mais difícil o objetivo, mais alto o nível do desempenho. Locke relata que objetivos específicos melhoram o desempenho e que o feedback também conduz a melhores desempenhos. 
Objetivos específicos difíceis produzem melhores resultados do que a meta genérica do “ faça o melhor que puder”. A especificação do objeto em si funciona como estímulo interno. Além disso, as pessoas trabalham melhor com feedback autogerenciado, ou seja, quando o funcionário é capaz de monitorar o próprio progresso. Este irá funcionar como um guia para o comportamento do empregado.

O autor também relata mais quatro fatores que influenciam a relação objetivo versus desempenho:

- comprometimento com o objetivo: o indivíduo está determinado a não abandoná-lo;

- a auto eficácia adequada: convicção individual de que se é capaz de realizar determinada tarefa;

- as características da tarefa: tarefas simples, familiares e independentes; e

- cultura nacional: adequada para países que não há uma grande distância do poder, que os empregados gostam de desafios e buscam conquistas materiais.

\subsubsection{0 - Teoria da Eqüidade}

Também chamada de Teoria do Equilíbrio, tem por base a crença de que as recompensas devem ser proporcionais ao esforço e iguais para todos. Se duas pessoas realizam o mesmo esforço, a recompensa deve ser igual à da outra ( ROBBINS, 2002).

A contribuição desta teoria no ambiente organizacional reside na possibilidade de se aferir o clima no trabalho, por permitir a compreensão quanto à reação das pessoas diante de recompensas oferecidas ao grupo. A percepção individual de eqüidade na distribuição destas recompensas se processa de forma comparativa entre as pessoas com base em quatro tipos principais de referências:

- A própria pessoa, numa posição ou situação diferente na mesma organização, que pode ser percebida como igual, melhor ou pior que a situação atual.

- A própria pessoa, numa situação diferente em outra organização, que pode ser percebida como igual, melhor ou pior que a situação atual.

- Outra pessoa ou grupo de pessoas, na mesma organização.

- Outra pessoa ou grupo de pessoa, em organizações diferentes. 
Estas medidas de comparação percebidas pelo indivíduo não resultam em conflitos no trabalho, haja vista que prevalece a eqüidade do comportamento, todavia, se há falta de isonomia no trato das pessoas, ter-se-á implicações motivacionais para a organização.

\subsubsection{1 - Teoria da Expectativa}

Proposta por Victor Vroom, esta teoria introduz elementos que procuram explicar como a influência das diferenças individuais produz algum tipo de motivação nas pessoas, convalidadas em suas crenças e expectativas, com base em três pontos ( ROBBINS, 2002):

- Relação esforço-desempenho: o desempenho que se alcança é proporcional ao esforço que se faz.

- Relação desempenho-recompensa: o esforço que se faz é proporcional ao valor que se dá à recompensa.

- Relação recompensa-metas pessoais: se a recompensa for atraente, a motivação para fazer o esforço será grande.

Esta teoria, ao colocar o esforço como variável dependente do valor percebido da recompensa associa três conceitos, cujos elementos são os seguintes:

- Valor da Recompensa - A recompensa é o elemento final da cadeia de causas e conseqüências e seu valor é relativo e depende de cada pessoa. Ingressar no serviço público, por exemplo, não interessa a um determinado indivíduo, portanto, não há valor a ser atribuído.

- Desempenho e Recompensa - É a crença de que o desempenho permite alcançar a recompensa. Se a recompensa é tornar-se servidor público é preciso passar no concurso.

- Esforço e Desempenho - Componente inicial da cadeia, a crença de que o esforço produz o desempenho. Se o desempenho consiste em passar no concurso, é necessário estudar.

Vroom desenvolveu uma teoria que reconhece a evidência de que diferentes pessoas reagem de diferentes maneiras, conforme a situação em que estejam colocadas, enfatizando assim as diferenças individuais.

Em face de todos os conceitos descritos sobre Teorias Motivacionais, um estudo realizado por Tadin (2005) conclui que: 
Ao contrário do que muitos pensam, não existe uma "fórmula" ideal para o uso da motivação humana. Existem sim resultados de pesquisas, que originaram teorias, as quais hoje nos servem de base para um encaminhamento dentro de nossa realidade.” Constata-se que, para um trabalho motivacional mais direcionado (onde as estratégias atinjam diretamente as necessidades do grupo ou indivíduo), é preciso um estudo mais profundo de casos específicos, em situações específicas de trabalho, conforme sugerem alguns autores que tratam do assunto. Assim, através de pesquisas e estudos, estabelece-se as necessidades de determinado grupo de trabalho e também o nível que cada uma dessas ocupa no processo de hierarquização. ( TADIN, et al., 2005, p. 46)

\section{5 - Satisfação/Insatisfação com o Trabalho}

Segundo Robbins ( 2002, p. 74), a satisfação com o trabalho trata-se de uma atitude geral de uma pessoa em relação ao trabalho que realiza. $\mathrm{O}$ autor lembra que esse trabalho não se refere apenas a tarefa exercida pelo empregado e sim a todo o ambiente que o cerca: colegas e superiores, obediência as regras e políticas organizacionais, alcance de padrões de desempenho e a aceitação de condições de trabalho, entre outros. Assim, a satisfação do funcionário com seu trabalho é um somatório de diferentes elementos. Um destes elementos é chamado pelo autor de procedimentos justos. Esses procedimentos de justiça estão relacionados com as ações do chefe, com os procedimentos da empresa, com a política de remuneração. Caso o empregado perceba que esses processos são justos dentro da empresa, isso irá gerar confiança, por parte do empregado, na organização.

Robbins ( 2002) ressalta que funcionários satisfeitos estão mais propensos a falar bem da organização, a ajudar os demais colegas, a ultrapassar as expectativas em relação ao trabalho, a ir além de suas atribuições regulares.

O autor tem avaliado que os fatores que motivam e trazem a satisfação são diferentes daqueles que insatisfazem. Para que haja satisfação profissional é necessário um relacionamento satisfatório com a equipe profissional, a possibilidade de obter crescimento profissional. Já a insatisfação está ligada com a remuneração, carga horária e responsabilidade assumida. 
A insatisfação, segundo Robbins ( 2002), é percebida por meio de quatro respostas que o funcionário passa dar em suas ações, que diferem entre si ao longo de duas dimensões, a dimensão construtiva versus destrutiva e a dimensão ativa versus passiva. As quatro respostas são definidas da seguinte forma:

- Saída: comportamento dirigido para o abandono da empresa, incluindo a busca de um novo emprego e a demissão.

- Comunicação: tentativa ativa e construtiva de melhorar as condições, incluindo a sugestão de melhorias, a discussão dos problemas com os superiores e algumas formas de atividade sindical.

- Lealdade: espera passiva, mas otimista, de que as condições melhorem, incluindo a defesa da organização às críticas externas e a confiança na empresa e em seus dirigentes, crendo que farão "a coisa certa”.

- Negligência: deixar as coisas piorarem, incluindo o absenteísmo ou atrasos crônicos, redução do empenho e aumento dos índices de erros.

Notamos que o absenteísmo, a baixa produtividade, a rotatividade, a falta de adaptação a tarefa desenvolvida, as condições do trabalho, a estabilidade/segurança, a auto-estima, o reconhecimento no desempenho profissional, entre outros, são fatores que estão estritamente ligados a insatisfação no trabalho. 
Foram realizadas entrevistas com o objetivo de aprofundar a pesquisa sobre o tema de motivação. A escolha da técnica de entrevista decorre do fato dela possibilitar o desenvolvimento de uma estreita relação entre as pessoas convidadas e o tema discutido, pois a pretensão é de se obter dados empíricos. A entrevistadora teve como finalidade extrair o máximo de informações, de conhecer as opiniões dos entrevistados, de explorar suas atividades dentro da empresa. O entrevistar guiou a conversação e os entrevistados responderam as perguntas expondo os fatos, as vivências que eles consideram mais relevantes ( RICHARDSON, 2008).

Em função da natureza do problema que se estudou, das questões e dos objetivos que orientam a investigação e com o intuito de obter dados descritivos sobre os fatores motivacionais do trabalho dos empregados da Empresa Atitude, o tipo de pesquisa utilizada foi a qualitativa. Esse tipo de pesquisa promoveu o contato direto da pesquisadora com a situação estudada, procurando compreender os fenômenos segundo a perspectiva dos participantes da situação em estudo. O método permitiu descobrir novas informações ou relações e permitiu verificar e ampliar o conhecimento existente. A preocupação fundamental da pesquisa qualitativa é o estudo e a análise do mundo empírico em seu ambiente natural ( GODOY, 1995).

A análise foi, quanto aos fins, descritiva e aplicada. Descritiva porque não há compromisso de explicar os fenômenos que serão descritos, muito embora servirão de base para tal explicação, e aplicada porque há necessidade de resolver problemas reais ( VERGARA, 1998). A pesquisa qualitativa descritiva trouxe uma visão ampla de como os empregados de uma empresa pública federal estão motivados, pois a pesquisa considera que todos os dados da realidade são importantes e devem ser examinados. A obtenção de dados descritivos por meio do processo interativo da pesquisadora com a situação estudada, pode comprovar fenômenos segundo a perspectiva dos participantes da situação em estudo ( GODOY, 1995).

Quanto aos meios de investigação, foi utilizado a pesquisa de campo. A pesquisa de campo consiste numa investigação empírica realizada no local onde ocorre ou ocorreu um fenômeno ou que dispõe de elementos para explicá-los ( VERGARA, 1998 ). 


\section{1 - Participantes da Pesquisa}

Vergara ( 1998) descreve que há necessidade de definir a população, que possuem as características que serão objeto de estudo. O autor define dois tipos de amostras: a probalística, baseada em procedimentos estatísticos, e a não probalística.

A amostra probabilística dividi-se em aleatória simples, estratificada e por congelamento. Este estudo irá utilizar a amostra probabilística estratificada. Ou seja, os entrevistados foram selecionados de acordo com uma amostra de cada grupo da população.

A pesquisa foi efetuada numa empresa pública federal, denominada Empresa Atitude, localizada em Brasília - DF, com representação em todas as capitais brasileiras. Todos os empregados são regidos pelo Decreto-Lei n 5.452 de $1^{0}$ maio de 1943 - Consolidação das Leis do Trabalho.

A força de trabalho desta empresa se compõe:

a) Empregados terceirizados: trabalham nas áreas de vigilância, limpeza e conservação predial, serviços de copa, recepção, entre outros.

b) Empregados requisitados de outros órgãos: ocupam cargos de chefia e assessoramento.

c) Empregados do quadro de pessoal da empresa: de nível fundamental, ocupante do cargo denominado auxiliar.

d) Empregados do quadro de pessoal da empresa: de nível médio e superior, com formações acadêmicas variadas, trabalhando na área meio da empresa, ocupantes dos cargos denominados técnico e analista, respectivamente.

e) Empregados do quadro de pessoal da empresa: de nível médio e superior, com formações acadêmicas específicas, trabalhando na área fim da empresa, ocupantes dos cargos denominados técnico e analista, respectivamente.

Assim, participaram desta pesquisa os empregados efetivos da empresa Atitude, das alíneas “c”, “d”, e “e”, no período compreendido entre $1^{\circ}$ a 30 de abril de 2009. Foram formados 2 (dois) grupos focais, de 5 (cinco) integrantes, e mais 5 (cinco) entrevistas individualizadas. Os entrevistados foram selecionados de acordo com a profissão, a idade, o sexo, o tempo de serviço. 
Entende-se por grupo focal um tipo de entrevista com uma considerável profundidade em realção ao tema abordado, possibilitando a análise da interação do grupo, tendo em vista que os participantes influenciam uns aos outros ( OLIVEIRA; FREITAS, 1998). Os grupos serão compostos por categorias diferentes, ou seja, serão separados por idade, cargo, tempo empresa.

O quadro a seguir descreve as características dos entrevistados:

\section{PERFIL DOS ENTREVISTADOS - QUADRO SINTÉTICO}

\begin{tabular}{|c|c|c|c|c|c|}
\hline Entrevistado & Cargo & Formação & Sexo & $\begin{array}{c}\text { Idade I } \\
\text { Intervalo }\end{array}$ & $\begin{array}{c}\text { Intervalo / Tempo } \\
\text { de empresa }\end{array}$ \\
\hline 1 & Analista & Nível Superior & M & 50 a 54 & 25 a 29 anos \\
\hline 2 & Auxiliar & Nível Médio & M & 45 a 49 & 25 a 29 anos \\
\hline 3 & Auxiliar & Nível Médio & F & 50 a 54 & 25 a 29 anos \\
\hline 4 & Auxiliar & Nível Médio & F & 45 a 49 & 25 a 29 anos \\
\hline 5 & Técnico & Nível Superior & F & 45 a 49 & 25 a 29 anos \\
\hline 6 & Técnico & Nível Médio & M & 30 a 34 & 1 a 4 anos \\
\hline 7 & Analista & Nível Superior & M & 25 a 29 & 1 a 4 anos \\
\hline 8 & Analista & Nível Superior & F & 35 a 39 & 1 a 4 anos \\
\hline 9 & Técnico & Nível Médio & F & 20 a 24 & 1 a 4 anos \\
\hline 10 & Analista & Nível Superior & M & 30 a 34 & 1 a 4 anos \\
\hline 11 & Analista & Nível Superior & M & 45 a 49 & 1 a 4 anos \\
\hline 12 & Analista & Nível Superior & M & 25 a 29 & 1 a 4 anos \\
\hline 13 & Auxiliar & Nível Médio & F & 40 a 44 & 25 a 29 anos \\
\hline 14 & Técnico & Nível Superior & F & 45 a 49 & 25 a 29 anos \\
\hline 15 & Técnico & Nível Médio & F & 20 a 24 & 1 a 4 anos \\
\hline
\end{tabular}

Os empregados da empresa Atitude possui um Plano de Cargos e Salários para cada categoria, neste plano há referências salariais. Os empregados são enquadrados de acordo com o tempo de serviço e seu deslocamento depende da nota de avaliação, num processo que a empresa chama de "Avaliação por Competências", e da ocorrência de vagas para o ingresso na referência seguinte. Em paralelo existe tabelas de gratificações para cada categoria, que corresponde a um percentual de 1\% (um por cento) a 60\% ( sessenta por cento) do salário do 
profissional. Estas gratificações são distribuídas por áreas e a divisão por empregado fica a cargo do chefe de cada área, o qual determina o percentual que será dado a cada empregado.

\section{2 - Instrumento da Coleta dos Dados}

As informações para se identificar as causas de desmotivação foram coletadas por meio de entrevistas individuais e entrevistas em grupos, tendo em vista a amplitude do tema, o qual envolve toda a organização, desde os empregados com cargas mais baixos, até àqueles empregados considerados de alto escalão.

A entrevista individual foi a primeira fase do processo. Ela foi realizada de maneira semi-estruturada e com um roteiro constituído de duas partes: a primeira voltada à caracterização dos sujeitos, e a segunda composta de questões abertas, norteadoras do estudo, tais como a compreensão que os empregados têm sobre o tema motivação, se eles se consideram motivados, o que acham que a empresa, que a gestão têm realizado a respeito desse tema. Os focos das questões foram de interesse amplo e a medida que as entrevistas evoluíam as questões ficaram mais específicas ( GODOY, 1995). Além de coletar os dados para a análise e discussão do tema, as entrevistas individuais também serviu para se aprimorar o roteiro de pesquisa, ajudando a construir os grupos de participantes e possibilitou exploração de novas questões surgidas nas análises das entrevistas.

As entrevistas permitiram aos entrevistados que desenvolvessem suas opiniões e informações da maneira que eles achassem conveniente. O objetivo da entrevistadora foi indicar o problema de pesquisa e as aspectos relevantes para serem tratados pelos participantes. As perguntas foram pré-formuladas, numa ordem preestabelecida, com a intenção de sugerir o tema de uma forma geral, levando o entrevistado a refletir ( RICHARDSON, 2008).

Ressalta-se que os entrevistados foram informados que a pesquisa não irá identificar os empregados. Essa informação, teve por objetivo de evitar as distorções que poderiam ocorrer, uma vez que os empregados poderiam ter receio da publicidade do que foi abordado.

\section{3 - Procedimentos da Coleta dos Dados}


Anteriormente à coleta de dados, a realização da entrevista foi precedida de prévia e expressa autorização da empresa em estudo. Após a autorização da empresa e após a apresentação dos objetivos do estudo, foi necessário se obter a autorização de cada participante, com a assinatura de um termo de consentimento, garantindo o caráter confidencial e voluntário da participação, e informando do compromisso de que, após concluído o estudo, haverá a comunicação aos participantes dos resultados.

As entrevistas foram realizadas e registradas diretamente pela pesquisadora, com o prévio esclarecimento dos objetivos do estudo. Foram feitas em horários e locais previamente marcados.

Neste caso, ao abordar a motivação nas organizações dentro da empresa, foram realizadas entrevistas com grupos focais e entrevista individuais, as quais foram semiestruturadas, gravadas e posteriormente houve a transcrição literal das entrevistas gravadas.

\section{4 - Análise dos Dados}

Os dados foram analisados por meio da análise de conteúdo. Entende-se por análise de conteúdo “a análise estática do discurso político” ( KAPLAN, 1943 apud RICHARDSON, 2008, p. 222).

Richardson ( 2008) ainda traz que análise de conteúdo defini-se como uma técnica que se baseia nos juízos de um analista ou grupo de analistas, por meio de um conjunto de instrumentos metodológicos cada dia mais aperfeiçoados que se aplicam a diversos discursos. Os instrumentos metodológicos são eles: objetividade, ou seja, clareza das regras e dos procedimentos utilizados; sistematização, refere-se a inclusão ou exclusão do material coletado que se irar utilizar; e inferência, é a parte em se aceita proposições em virtude de outras consideradas como verdadeiras. O autor ainda acrescenta:

A análise de conteúdo é um conjunto de técnicas de análise das comunicações visando obter, através de procedimentos sistemáticos e objetivos de descrição do conteúdo das mensagens, indicadores ( quantitativos ou não) que permitam inferir conhecimentos relativos às condições de produção / recepção ( variáveis inferidas) dessas mensagens. ( BARDIN, 1979 apud RICHARDSON, 2008, p. 223). 
Portanto, devido a natureza da coleta de dados ser qualitativa a utilização da análise de conteúdo permitiu uma melhor compreensão do discurso dos entrevistados, de aprofundamento das características discutidas e extração dos momentos mais importantes das falas.

A análise de conteúdo das transcrições será separada da seguinte forma:

1. identificar os temas comuns;

2. verificar se a percepção do tema é comum entre os entrevistados;

3. quais fatores influenciam as percepções individuais dos entrevistados 


\section{4 - Resultados e Discussão dos Resultados}

Este item contém os resultados obtidos a partir das entrevistas qualitativas individuais e de grupos focais com os empregados ocupantes de cargos de nível fundamental ( auxiliares), de nível médio ( técnicos) e de nível superior ( analistas) da Empresa Atitude. Os resultados refletem as percepções dos indivíduos entrevistados sobre o tema motivação na execução das atividades de trabalho, tomadas em relação ao referencial teórico sobre o tema.

Para facilitar a compreensão, a apresentação será separada por categorias de acordo com os cargos que cada profissional ocupa. Foram apresentadas as considerações sobre: o diaa-dia do empregado na organização; as possíveis causas e razões de desmotivação no trabalho; qual o nível de influência da organização nestas causas; se a gestão no trabalho, a pressão no trabalho, a falta de variedades nas tarefas, a falta de flexibilidade contribuem para desmotivar; como os entrevistados visualizam todo corpo funcional no que diz respeito a motivação; e o que a organização pode fazer, do ponto de vista dos empregados, para motivar seus colaboradores.

O processo das entrevistas seguiu as seguintes instruções (RICHARDSON, 2008):

1. Explicação do objetivo e natureza deste trabalho, assegurando o anonimato e sigilo das repostas;

2. Explicação de que o entrevistado pode se sentir livre para pedir esclarecimentos, falar sobre sua própria experiência.

3. Antes de iniciar, o entrevistado respondeu a um pré-questionário com dados para identificação sócio-demográficas, tais como: número da entrevista, data, lugar, sexo, idade, nível escolaridade, ocupação.

\section{1 - Execução das Tarefas}

Em virtude do objetivo geral do presente trabalho ser analisar se os empregados da Empresa Atitude estão desmotivados na execução dos seu trabalhos e no alcance dos resultados organizacionais, procurou-se verificar, na primeira pergunta feita aos entrevistados, 
como é o dia-a-dia dos profissionais dentro da Empresa Atitude, como é o dia-a-dia no trabalho.

Por meio das entrevistas, verificou-se que, de acordo com os cargos que cada empregado ocupa, há uma diversidade de respostas para um mesmo tema.

Nota-se, que os empregados, ao abordar o tema dia a dia na execução das tarefas, associam a tarefa executada com a responsabilidade assumida e, por isso, o grau de importância da tarefa está ligado com a responsabilidade que provém dela.

De início, observa-se que os empregados dos cargos de nível fundamental, consideram as tarefas que lhe são atribuídas bastantes complexas, estando além de suas expectativas para o cargo ocupado. Para eles a complexidade da tarefa vem a gerar excesso de responsabilidade, como demonstram os trechos dos depoimentos a seguir:

"Existe muita rotina no meu dia-a-dia de trabalho. Há excesso de responsabilidade na execução das tarefas. ”( Entrevistado $\mathrm{n}^{\circ} 13$ ).

“O dia a dia é bom, pois não é um serviço rotineiro. Agora, por outro lado, a responsabilidade é maior do que eu esperava.” ( Entrevistado $\mathrm{n}^{\circ}$ 3).

“No meu caso, não é o que eu esperava, há muita demanda e às vezes sintome meio confusa na finalização, por não entender bem até que ponto a demanda toda é de minha alçada.” ( Entrevistado $n^{\circ} 4$ ).

O trecho acima do entrevistador de $n^{\circ} 4$ ( quatro), demonstra a falta de compreensão da execução das atividades, evidenciando a necessidade de se articular a meta do trabalho com clareza, pois caso não ocorra, “ a frustração de rodar em círculos e não sair do lugar, abala a vida interior no trabalho, derrubando a motivação” ( AMABILE, T.M. et al, 2007, p.42 apud BERGAMINI, 2008, p. 72). Nas demais respostas, também pode-se observar que a rotina, o excesso de atividades e o alto grau de responsabilidade estão frustando a satisfação dos empregados em relação ao conteúdo do cargo e a natureza das tarefas. A Teoria dos Dois Fatores de Herzberg denomina como fatores motivacionais ou intrínsecos, àqueles relacionados com a execução das tarefas e se esses fatores estiverem frustrados ocorrerá a desmotivação do empregado, a perda do interesse pelas tarefas. Verifica-se também, que como a responsabilidade atribuída chega a ser excessiva, este fator vem a comprovar o que 
Robbins (2002) menciona: se o grau de responsabilidade for intenso, isso pode levar o homem a insatisfação no trabalho.

Já os empregados que ocupam os cargos de nível médio, consideram que as tarefas estão de acordo com o esperado e o grau de responsabilidade condiz com o cargo.

“As funções que desenvolvo têm muito haver com meu perfil. O serviço é muito administrativo, burocrático e simples. Dentro do meu cargo, fiquei num posto que considero ter as melhores tarefas a serem desenvolvidas." ( Entrevistado $\left.n^{0} 15\right)$.

“Meu dia-a-dia no trabalho não é prazeroso, porém é tolerável. Há grandes rotinas, mas prefiro assim do que as outras possibilidades apresentadas pela Empresa. Portanto, as rotinas e as responsabilidades estão de acordo com minhas expectativas." ( Entrevistado $\mathrm{n}^{\circ} 6$ ).

"As tarefas que desenvolvo no meu dia-a-dia estão mais voltadas para demandar do que executar. Portanto, o resultado final depende de outros fatores e pessoas envolvidas nas tarefas. Gosto do que faço. As dificuldades que surgem são decorrentes de falhas com equipamentos, no sistema. Em se tratando dos colaboradores, eu consigo fazer com que eles cumpram as tarefas, além do que lhe são destinados.” ( Entrevistado $\mathrm{n}^{\circ}$ 9).

A resposta do participante de $n^{\circ} 9$ ( nove), revela que para que as tarefas sejam bem executadas é necessário trabalho em equipe. O entrevistado, por ter tarefas mais voltadas a demandar, constata que o resultado final de seu trabalho depende de outras pessoas e nos mostra seu envolvimento e responsabilidade para conseguir com que seus colaboradores ultrapassem as expectativas do trabalho. Este comprometimento dos colaboradores com o negócio e as tarefas, conseguido pelo participante $n^{0} 9$ ( nove), é mencionado por Maslow como uma necessidade social e seu surgimento significa que os empregados se sentem reconhecidos dentro da equipe de trabalho. Robbins ( 2002) acrescenta que um relacionamento satisfatório com a equipe profissional leva à satisfação profissional. 
Já os trechos abaixo, revelam o que David McClelland definiu como Necessidades de Realização. As expressões “Se alguém não executa, eu vou lá e faço” ( Entrevistado de n 14) e “... muita responsabilidade... isso é extremamente motivador” ( Entrevistado de $n^{0} 5$ ) mostram que certos empregados puxam para si e assumem as responsabilidades. Preferem trabalhos com bastante responsabilidade e um grau médio de riscos.

“O meu dia-a-dia é extremamente técnico e gerencial. Eu gosto de gerenciar pessoas, fiz treinamento para isso. Se alguém não executa, eu vou lá e faço. Depois, procuro saber o que faltou, onde está a falha." ( Entrevistado $\mathrm{n}^{\circ} 14$ ).

“As tarefas são altamente dinâmicas e de muita responsabilidade. Assuntos diferentes a cada momento. Para mim, isso é extremamente motivador para continuar aqui. Gosto muito do que faço. ( Entrevistado $\mathrm{n}^{\circ} 5$ ).

Em relação aos empregados de nível superior, eles classificam o trabalho diário com uma quantidade considerável de rotina, mas no geral gostam do que fazem. Mesmo pertencendo ao mesmo tipo de cargo, vindo a modificar a especialização de cada cargo, verificou-se que há cobranças em relação a responsabilidade. Acham importante ter responsabilidade e por isso, quando não possuem, descrevem esta ausência como um fato negativo. E para àqueles que têm, acreditam que treinamento profissional agregaria de maneira considerável ao desempenho das tarefas.

“Há muita responsabilidade, porém sinto falto de estrutura, treinamento e perfil para desenvolver as tarefas que me foram passadas. Não me acho preparado para executar as tarefas que desempenho, não tenho uma estrutura técnica. Mas, no geral, é bom e eu gosto.” ( Entrevistado $\mathrm{n}^{\circ} 7$ ).

"Eu chego com boas expectativas. Venho consciente de que tenho de resolver tudo aquilo que não resolvi no dia anterior e tudo aquilo que possa a vir a acontecer naquele dia. Tento estar receptivo as soluções, para não deixar de resolver nenhum problema." (Entrevistado $\mathrm{n}^{\mathrm{0}} 10$ ). 
"Considerando que as atividades são geradas por demanda, existem rotinas repetitivas e intrínsecas ao exercício da função. Porém, sendo o atendimento em ambientes físicos distintos, os desafios são semelhantes, mas quase sempre há novidades devido os aspectos diferenciados. O grau de responsabilidade é estático, frusta a busca de maiores desafios.”( Entrevistado $\left.\mathrm{n}^{\circ} 11\right)$.

O trecho acima, Entrevistado $\mathrm{n}^{\circ}$ 11, evidencia o que a Teoria $\mathrm{Y}$ e a Teoria das Necessidades de McClelland relatam. A primeira descreve que o homem puxa para si responsabilidade e a segunda considera que a responsabilidade é um atributo para a realização profissional, quando ela não existe o indivíduo se sente frustrado.

\section{2 - Fatores motivacionais}

A segunda pergunta abordou o tema motivação. Foi perguntado aos entrevistados o que eles apontam como fatores que levam os profissionais da Empresa Atitude a se motivarem ou desmotivarem.

Para os profissionais dos cargos de nível fundamental o principal fator é o financeiro. A baixa remuneração, aliada a falta de ascensão profissional dentro do cargo, leva os profissionais a se desmotivarem.

“O novo plano de cargos e salários não beneficiou a categoria. Não há mais perspectiva de progressão funcional. A empresa acabou com a carreira e desprezou de 20 a 35 anos de profissão.”( Entrevistado $\mathrm{n}^{\circ} 2$ ).

“Quando você tem uma responsabilidade grande e não ganha por isso, isso desmotiva." (Entrevistado $\left.n^{\circ} 3\right)$.

Os empregados de nível médio consideram que à rotina, a falta de perspectiva de crescimento profissional, a ociosidade, a falta de equilíbrio do volume das tarefas aliado ao grau de dificuldade, são fatores que podem desmotivar. 
"O que me motiva é desafio e eu não tenho. É muita rotina. Aliado a isso vem

a falta de perspectiva de ascensão profissional. Só há uma maneira de crescer: tem que virar chefe.”( Entrevistado $\left.\mathrm{n}^{0} 15\right)$.

“Os altos e baixos da demanda geram falta de equilíbrio. Tem dias que não tem quase nada para fazer. A ociosidade, as tarefas sazonais me desmotivam. O grau de dificuldade também desmotiva. Tem coisas que você faz e que você sabe que poderia fazer muito mais. O que me motiva são mais tarefas e mais responsabilidade."( Entrevistado $\mathrm{n}^{\circ} 6$ ).

“ O que motiva para mim é o nível de responsabilidade que as tarefas trazem. A medida que a responsabilidade vai aumentando e eu me sinto mais atarefada e sobrecarregada, fico mais feliz. Não quero diminuir o ritmo. A ociosidade me desmotiva."( Entrevistado $\mathrm{n}^{\circ}$ 9).

Na expressão “ A medida que a responsabilidade vai aumentando e eu me sinto mais atarefada e sobrecarregada, fico mais feliz”, Entrevistado $\mathrm{n}^{\circ} 9$, e “ atender as expectativas $e$ superá-las”, Entrevistado $\mathrm{n}^{0} 12$, verifica-se que a necessidade de auto-realização encontramse totalmente satisfeita. Estes empregados buscam a satisfação intrínseca.

Para os empregados de nível superior, os fatores mais importantes que possam motivar referem-se ao atendimento das tarefas, ao lado dinâmico que as tarefas devem ter e ao fator financeiro condizente com a tarefa realizada.

“ O que mais me motiva é atender as expectativas e superá-las ." (Entrevistado $\mathrm{n}^{\mathrm{o}}$ 12).

"Rotina muito maçante desmotiva. O que motiva são as novidades." (Entrevistado $\left.\mathrm{n}^{\circ} 14\right)$.

"Como em qualquer outra atividade, a rotina e a falta de objetividade desmotivam o trabalho. A motivação passa a ser fruto do reconhecimento hierárquico, devidamente gratificado e focado em desafios." (Entrevistado $\mathrm{n}^{\circ}$ 11). 
"O que desmotiva é saber que pessoas não qualificadas o bastante, que desempenham tarefas não tão importantes, não tão cruciais e que ocupam cargos sem expressão, recebem os melhores salários. O critério de distribuição financeira não é uma maneira isonômica. Existe o favorecimento. Então, temos de um lado uma pessoa extremamente capaz, que tem suas funções laborais bem desempenhadas, muito exigidas, bem cobradas, responsabilidade de caráter altíssimo e que não é condizente com o seu retorno financeiro.”(Entrevistado $\left.\mathrm{n}^{\mathrm{o}} 10\right)$.

Quando o Entrevistado de n ${ }^{\circ} 10$ revela que a sua desmotivação está relacionada com a falta de critérios isonômicos de distribuição de financeira, este dado vem a confirmar o que a Teoria de Eqüidade revela: que a falta de isonomia no trato das pessoas, irá gerar implicações motivacionais para a organização. Esta teoria descreve que o indivíduo tende a comparar as avaliações que recebeu com as avaliações feitas a outras pessoas, buscando a justiça pelos mesmos padrões que avaliam os demais e fugindo do sentimento de iniqüidade ou injustiça que possa sentir ( BERGAMINI, 2008).

\section{3 - Responsabilidades da organização sobre a motivação}

A terceira questão tratou do papel da organização em referência ao tema motivação. Até que ponto a organização do trabalho pode contribuir para motivar ou desmotivar seu colaborador.

Verificou-se nas respostas diversidades de pensamentos. Para os profissionais das cargos de auxiliares a organização deixa a desejar quando não promove políticas de qualidade de vida. Para eles, a organização tem que promover meios que evidenciem a valorização do profissional, tem que acompanhar a divisão das tarefas, evitar a sobrecarga. A expressão abaixo "valorização pessoal”, denota a falta do reconhecimento que o empregado do cargo de auxiliar vem sentido. Os últimos concursos públicos não abriram vagas nesta área, este fator evidencia a intenção da empresa em extinguir o cargo. Após a realização dos concursos, suprindo a carência de vagas, muitas das atividades que os auxiliares executavam foram repassados a outros empregados. 
“A organização tem que introduzir políticas de qualidade de vida na empresa, de valorização pessoal e de divisão das tarefas."(Entrevistado $\mathrm{n}^{0}$ 13).

Os demais ainda trouxeram que não há políticas de crescimento profissional, com critérios claros e objetivos. Verifica-se a negligência da empresa nestas políticas, tanto nas respostas dos empregados dos cargos de nível médio (Entrevistados $\mathrm{n}^{0} 15$ e $\mathrm{n}^{0}$ 5), quanto nas respostas dos empregados dos cargos de nível superior (Entrevistados $n^{\circ} 10$ e $\left.n^{\circ} 11\right)$ :

“A organização desmotiva quando fica omissa nas políticas de ascensão profissional.” (Entrevistado n $\left.{ }^{0} 15\right)$.

"Quando não introduz um plano de cargos e salários que possibilite uma escalada, independente de quem está avaliando. A progressão funcional deve ocorrer pelos méritos e conquistas de cada empregado." (Entrevistado n $\left.{ }^{0} 5\right)$.

“Falta um programa com critérios, orientações, nas quais a empresa possa avaliar as pessoas dentro de suas atividades, atribuindo degraus de importância. Falta desenvolver um perfil dentro de cada área, de maneira que a empresa possa avaliar, qualificar, quantificar e atribuir valores para um retorno, seja ele financeiro, material, recursos humanos.” (Entrevistado $\left.n^{\circ} 10\right)$.

A resposta do Entrevistado de $n^{0} 10$ ( dez), vem a confirmar o que Bergamini ( 2008) caracteriza de ação consciente. A autora descreve que os empregados têm que saber, da forma mais clara que houver, o que buscam, têm que conhecer aquilo que está acontecendo dentro da empresa, pois será por meio deste conhecimento que passarão a saber como devem agir para poder chegar até onde pretendem, para tomarem o rumo certo que pode levar à sua maior satisfação motivacional.

“ A organização do trabalho pode desmotivar o indivíduo quando aceita práticas de paternalismo, nepotismo, formando uma cadeia de 
favorecimentos mútuos, fazendo com que a fidelidade se sobressaia a competência.” (Entrevistado $\left.n^{\circ} 11\right)$.

A omissão da organização na implantação de políticas de qualidade de vida, de ascensão profissional e a aceitação de práticas de nepotismo e favorecimento, sugerem o grau de responsabilidade que a empresa possui, prejudicando a imagem e a credibilidade da empresa diante de seus colaboradores.

Outro ponto abordado pelos entrevistados e que gera desmotivação são as mudanças de políticas de gestão estratégica dentro da empresa.

“As mudanças de direcionamento estratégico da empresa. A cada modificação de dirigentes, mudam-se todo o planejamento estratégico. Até que alguém esclarece algo, vamos para essa ou aquela direção, você fica sem rumo." (Entrevistado $\mathrm{n}^{\circ}$ 5).

“Não tem um desenvolvimento contínuo. Deveria ter um política desencadeada." (Entrevistado $\left.\mathrm{n}^{\circ} 14\right)$.

Os entrevistados também enfatizaram que a organização do trabalho deva promover a mobilidade entre as áreas, procurando verificar onde cada profissional poderá melhor desenvolver suas tarefas, observando se a mudança não irá prejudicar o planejamento de cada área.

“A organização tem que oferecer oportunidades para o empregado escolher que tipo de atividade quer desenvolver. Quando a organização não permite essa mobilidade ela promove a desmotivação. Tem que ter respeito pelos dons que cada profissional, por sua vocação.” (Entrevistado ${ }^{\circ} 1$ ).

“A falta mobilidade dentro da empresa prejudica o desenvolvimento das tarefas.” (Entrevistado $\left.n^{\circ} 8\right)$.

“ A mobilidade tem que acontecer, desde que se observe o lado da empresa. Há um planejamento que deva ser observado e um conhecimento que deva ser 
repassado. Quando o empregado fala que não tem mobilidade, ele não vê o lado da empresa, de quem está pagando o salário dele. Ele vê apenas o seu lado egoístico." (Entrevistado $\mathrm{n}^{0}$ 5).

\section{4 - Gestão da motivação}

A quarta questão tratou da gestão, de como ela pode promover motivar os indivíduos no trabalho.

Sabe-se que “ a gestão da motivação diz respeito, sobretudo, às práticas das quais as organizações se servem do que às expectativas dos indivíduos” ( MICHEL, 1994, p.11 apud BERGAMINI, 2008, p. 71). Para Bergamini ( 2008), cabe a organização descobrir quais são as práticas que tem que utilizar para motivar seus colaboradores, uma vez que um trabalhador pode considerar que motivação para o trabalho não representa uma necessidade absoluta em sua vida.

Com base nas respostas dos participantes, verifica-se que a empresa Atitude não promove ações voltadas para o conhecimento das necessidades de seus empregados. Portanto, se cabe a empresa Atitude a responsabilidade de gerenciar a motivação, esta pratica está longe de se atingida, uma vez que não foram introduzidos procedimentos eficazes para motivar.

Os participantes mencionaram que há necessidade de se individualizar o tratamento de seus colaboradores. Os responsáveis em gerenciar outros funcionários devem ter sensibilidade de conhecer cada subordinado, para com isso identificar qual a tarefa que melhor se enquadra no perfil daquele funcionário e que o reconhecimento parte do chefe imediato. Pode-se verificar que o empregado vê que a organização é a responsável em reconhecer a importância de que cada atividade. $\mathrm{O}$ chefe imediato passa a ser o meio pelo qual o empregado espera ser reconhecido dentro da empresa. Seja com cursos de capacitação, seja para entender e desenvolver o perfil de cada empregado, seja para elogiar as tarefas bem desenvolvidas ou seja para corrigi-las de maneira educada e discreta.

“ A gestão deve ter a sensibilidade de identificar se o empregado está assoberbado de demandas. Deve promover a capacitação do empregado. Pois, esta prática, além de motivar, promove o reconhecimento do profissional.” (Entrevistado $\left.\mathrm{n}^{0} 13\right)$. 
“ A gestão deve respeitar e reconhecer o perfil do subordinado, para poder alocá-lo de acordo com sua vocação. (Entrevistado $\mathrm{n}^{\circ}$ 6).

"O grande mérito das chefias é saber demostrar liderança e confiabilidade, com objetivos claros e sinceros.” (Entrevistado $\left.\mathrm{n}^{\mathrm{0}} 11\right)$.

“A gestão deve tentar qualificar, quantificar e avaliar o desempenho de seus subordinados, com o objetivo de valorar e valorizar a função de cada um. A gerência tem que identificar o que significa reconhecimento para cada empregado, para saber o que cada um precisa para seu reconhecimento. E quando digo reconhecimento, entenda-se aí a motivação. O reconhecimento na verdade é a motivação que cada a pessoa tem. Se ela não tem reconhecimento, ela não está tendo motivação. (Entrevistado $\left.\mathrm{n}^{0} 10\right)$.

O trecho acima revela o quanto o empregado menciona a responsabilidade do gerente de conhecer seus colaboradores. Bergamini ( 2008) nos revela que devido ao caráter consciente que cada indivíduo tem a respeito de motivação, o empregado não admite mais ser manipulado. Portanto, "seus líderes devem ser autênticos, saudáveis psicologicamente e seguros de si, devido à sua verdadeira auto-estima que lhes é característica”. A autora traz conclusões observadas por Maslow, A. ( 2000, p.110 apud BERGAMINI, 2008, p.76) a respeito dos melhores gerentes: eles são pessoas psicologicamente saudáveis, diferentes dos gerentes considerados ruins, e por isso aumentam a saúde dos trabalhadores que gerenciam. A autora acrescenta que devido a impossibilidade da organização em se ter um setor organizacional responsável pela motivação, caberá então à empresa preparar líderes capazes de agir de forma a garantir e aumentar a motivação de seus subordinados e colocar a disposição dos gerentes as melhores e mais atuais informações sobre comportamento humano. O líder se caracteriza é aquele executivo que aponta a direção que a organização tem que seguir, cria a visão de futuro, tem que ter a capacidade de fazer com que os empregados, incluindo àqueles do alto escalão, aceitem e implementem idéias novas. Ele não pode ser confundido com o gerente, este é o responsável em "manter o bom funcionamento da organização, preservando sua identidade através dos tempos”( KOTTER, 1997, p. 6 apud BERGAMINI, 2008, p.78) 
A resposta abaixo, vem a confirmar as propostas feitas por Edwin Locke, na Teoria da Fixação de Objetivos, ou seja, a necessidade que o empregado possui de que a gerência saiba demandar o trabalho de forma clara e objetiva. Os objetivos devem ser específicos, pois isso irá melhor o desempenho do empregado. A expressão "elogiando o trabalho quando é feito de maneira correta" deixa claro a necessidade do feedback, fator que também contribui para melhores desempenhos

“A gestão pode motivar o indivíduo passando metas claras, elogiando o trabalho quando é feito de maneira correta e não só criticando. O chefe tem que ser educado e provocar um clima agradável no setor." (Entrevistado $\mathrm{n}^{\circ}$ 7).

\section{5 - Pressão no trabalho}

Em referência ao tema pressão, os empregados entrevistados identificaram um único mecanismo de pressão: os prazos vinculados à lei. A empresa por pertencer ao governo federal está obrigada a cumprir as leis.

“Não há pressão. Pressão é roubar idéias, trabalhos, é quando o superior hierárquico roubar suas idéias. Conceituo como pressão psicológica.” (Entrevistado $\left.\mathrm{n}^{\circ} 14\right)$.

"A área que eu trabalho o prazo é a maior pressão. A minha área é muito operacional. Trabalho muito com resultados, com produção, com prazos exigidos por lei. (Entrevistado $\mathrm{n}^{0} 5$ ).

“Não consigo visualizar. Além daquelas pressões do dia a dia, de exigências de cumprimento de prazo, por causa da lei 8.666/93 e outras.” (Entrevistado $\left.n^{0} 1\right)$. 
"Uma pressão relacionada aos prazos para a execução das tarefas. Mais tolerável na medida que se tem uma rotina de trabalho definida, um conhecimento do que se faz e desempenho dentro esperado." (Entrevistado $\mathrm{n}^{\circ}$ 10).

\section{6 - Diversidade na execução das tarefas}

Tratou-se também da falta de variedade de tarefas, se elas podem desmotivar o indivíduo. Algumas respostas mostraram que diversificação de tarefas é um fator que influencia extremamente a motivação dos empregados

“Tem muita falta de diversidade nas tarefas que realizo. Esta ausência de variedades leva a rotina e a rotina gera insatisfação."(Entrevistado ${ }^{\circ} 3$ ).

Tem-se que ter cuidado quando não há diversidade de tarefas. Pois, quando você entra no comum, na rotina, no dia a dia da mesmice, àquelas tarefas que no começo o empregado adorava realizar, não deslumbram mais. Elas não prendem mais a atenção. E aí, corre o risco do empregado entrar no comodismo.(Entrevistado ${ }^{\circ}$ 9).

“Gosto de variar, sair da rotina, aprender coisas novas, novos desafios. Quando não consigo variar as tarefas, fico frustrado e desanimado. (Entrevistado $\mathrm{n}^{\circ}$ 7).

Outros entrevistados, no entanto, diz que diversidade de tarefas está ligado a personalidade de cada um e as tarefas desenvolvidas. Alguns empregados, por medo de aprender novas atividades, detestariam a variedade de tarefas. Outros, por considerar o alto nível de responsabilidade e de importância da tarefa, consideram benéfico a falta de diversidade. 
"Não existe uma variação de atividades nas tarefas que desenvolvo. Considero isso é sadio, pois as tarefas são importantes para o setor e com grande nível de responsabilidade.(Entrevistado $\left.\mathrm{n}^{\circ} 10\right)$.

“A falta de variedades nas tarefas não é algo desmotivante. A rotina não gera desmotivação, pois minha rotina está vinculada a muita responsabilidade e a importância do meu trabalho.” (Entrevistado $\left.\mathrm{n}^{\circ} 11\right)$.

Os trechos acima também revela uma motivação intrínseca do indivíduo. Como consideram suas atividades importantes, o fator diversidade não provoca desmotivação, pois a importância atribuída a tarefa leva o empregado a valorizar o seu trabalho.

\section{7 - Flexibilidade na execução das tarefas}

Os entrevistados também responderam ao tema flexibilidade na organização. Tentouse identificar como a Empresa Atitude trata a flexibilidade organizacional e se a falta de flexibilidade pode desmotivar os funcionários da organização.

Os participantes consideram que a falta flexibilidade desmotiva, mas no caso da empresa Atitude, ela está ligada ao fato da empresa ser estatal. Sendo seu capital financeiro cem por cento público, ela passa a ser regida por leis de ordem federal. Logo, os empregados consideram que a flexibilidade não está ligada aos fatores que os motivam ou desmotivam, os empregados conseguem abstrair o fator flexibilidade.

“A falta de flexibilidade desmotiva. Mas, não levo este fator em consideração, pois estamos no serviço publico e sabemos que a culpa não é da empresa. A área pública é engessada por lei externas e internas.(Entrevistado $\mathrm{n}^{\mathrm{o}}$ 3).

"Existe flexibilidade na realização dos procedimentos operacionais e flexibilidade de horário. Não há flexibilidade na execução das tarefas, porque 
estão vinculadas à lei. Mas, esta falta de flexibilidade não influencia minha motivação.” (Entrevistado nº 9).

"Não vejo que a flexibilidade seja um fator que possa influenciar a motivação. Entendo que flexibilidade esteja associada a responsabilidade que a tarefa desempenhada possui." (Entrevistado $\mathrm{n}^{\mathrm{0}} 11$ ).

\section{8 - Percepção das empregados sobre o motivação do quadro funcional}

Com a intenção de verificar qual a avaliação que os entrevistados fazem, de maneira geral, sobre a motivação de todo corpo funcional, foi pedido a cada participante que manifestasse sua opinião sobre como consideram os empregados desta organização: estão motivados ou não. Pediu-se também, que, caso achassem necessário, realizassem a avaliação diferenciando os empregados com mais de 20 ( vinte) anos de serviço, daqueles com cerca de 1 ( um) ano a 5 (cinco) anos de serviço.

Verificou-se que os empregados que ocupam os cargos de nível fundamental consideram que todo o corpo funcional está desmotivado e os motivos que geram esta desmotivação geral são os baixos salários e a falta de qualificação dos chefes. Esta categoria, ao considerar que os salários estão reduzidos e que se houvesse acréscimos salariais, isto poderia incentivá-los a trabalhar mais, vem a confirmar o principal argumento utilizado por Taylor, seja ele: que o salário é o principal fator de motivação. Em referência ao segundo ponto, nota-se que os empregados sentem falta de um canal de comunicação aberto, o qual seria exposto seus problemas.

"Em geral desmotivados. Razão: chefes despreparados para motivar. A pessoa vira chefe, mas não é capacitado para gerenciar pessoas. Nenhum chefe se preocupa em saber o que o empregado está sentindo, o que ele quer. Não há liberdade para falar sobre o tema."(Entrevistado $\left.\mathrm{n}^{\circ} 2\right)$. 
Os empregados estão desmotivados devido aos baixos salários. Se o salário for muito bom, darei o meu máximo.” (Entrevistado $\left.\mathrm{n}^{\circ} 4\right)$.

A expressão “Se o salário for muito bom, darei o meu máximo.” confirma a relação desempenho-recompensa da Teoria da expectativa, onde o esforço que se faz é proporcional ao valor que se dá à recompensa. Ou seja, para Entrevistado nº 4 ( quatro) um salário alto seria uma grande recompensa, portanto ele iria desempenhar da melhor forma possível suas tarefas, para obter a recompensa.

Os empregados dos cargos de nível médio adicionam novos fatores, os quais reconhecem que levam à desmotivação de todo o corpo funcional. As respostas revelam que existe sobrecarga de trabalho aliado a excesso de cobranças, engessamento na progressão funcional e que não há reconhecimento profissional por parte da organização. Vale lembrar, o que Chanlat ( 2002) descreve sobre reconhecimento: é uma fator que faz com que o trabalho seja interessante e produz conseqüências sobre a motivação para o trabalho.

“Todos desmotivados. Acredito que a razão seja a falta de reconhecimento. Não cabe reclamar somente sobre a questão do baixo salário. Cada um quando entrou sabia o quanto iria ganhar.” (Entrevistado $\left.n^{\circ} 9\right)$.

"No geral, vejo todos os empregados desmotivados. Para os empregados recém contratados a razão deve-se aos baixos salários, a quantidade reduzida de trabalhadores, a falta de realização profissional. Aliado a este fatores, vem o excesso de cobranças. Para os empregados mais antigos, muitos com gratificações máximas, não há mais como ter aumentos. Por isso, não dão mais o melhor de si." (Entrevistado $\left.n^{\circ} 15\right)$.

“A grande maioria dos empregados estão desmotivados. Tanto àqueles com mais tempo de serviço, devido à rotina, ao salário ou a falta de políticas de motivação proporcionadas pela empresa, quanto os empregados com menos tempo de casa, devido ao baixo salário, a falta de espaço para crescimento profissional.” (Entrevistado $\left.\mathrm{n}^{\circ} 6\right)$. 
"Tanto os empregados mais antigos, quanto os mais novos estão desmotivados. Falta plano de cargos e salários decente. Aumentam a gratificação por meio de uma política paternalista. É um problema gerencial.” (Entrevistado $\left.n^{\circ} 14\right)$.

Os participantes também revelaram outra questão que pode ter levado a desmotivação dos empregados: ingresso na empresa em épocas distintas, com particularidades opostas. Esta avaliação foi feito por empregados dos cargos técnicos (Entrevistado $n^{0} 5$ ) e dos cargos de analistas (Entrevistado nos.: 1,10,11,12).

“Existiu uma época bem melhor. Todo esse pessoal que entrou nos últimos concursos, foi um banho de água fria. A gente já teve ideais, vestiu a camisa, conhecemos a história da empresa, estamos sempre envolvidos com projetos voltados para empresa. As expectativas dos novatos são outras e elas nunca estão voltadas para empresa. Hoje em dia existe muitas vagas de concursos públicos, com salários variam de $R \$ 700,00$ a $R \$ 19.000,00$. O novos empregados entraram na empresa Atitude ganhando 2 (dois) mil reais, um ano depois ganharam mais 1 (um) mil reais. Mesmo assim, não estão satisfeitos, porque existe um leque muito grande lá fora. Não dá para confundir com o que acontece aqui dentro. Aqui dentro cada um sabia até onde poderia ir. Para os novatos a empresa Atitude é mais uma tentativa. Não estão motivados porque estão com um pé lá fora. Essa é a sensação que tenho. Nenhum novato está com os dois pés dentro da empresa. O fato de terem entrado, não quer dizer que conseguiram o que queriam tanto. Você pode ficar horas tentando convencer uma pessoa de que o trabalho dela é legal, que o aprendizado é bacana, que vai levar uma bagagem para diferenciá-lo. Não adianta. É difícil convencer que esses argumentos são motivadores para se está aqui com os dois pés. As pessoas vão está sempre insatisfeitas, achando que aqui é o pior lugar, que podia ser diferente, que poderiam está ganhando mais. E com essas expectativas negativas, passa a vê somente o lado negativo, isso impede a entrega." (Entrevistado ${ }^{\circ} 5$ ). 
O trecho acima vem a confirmar o que Robbins ( 2002) nos revela em seus estudos. Para o autor, o nível de motivação de cada empregado varia tanto entre indivíduos, quanto para indivíduos em tempos diferentes. Nota-se no depoimento, que o principal fator que leva a desmotivação daqueles empregados recém contratados é a possibilidade que o mercado de trabalho oferece nos dias atuais. Os altos salários que são pagos por algumas organizações geram desconfortos em empregados que não recebem tão bem e não encontram na organização, a qual pertence, perspectivas de igualar aos salários praticados por outras organizações.

A resposta também evidencia a questão de valor, confirmando o que Bergamini ( 2008) nos mostra, ou seja, que significado e valor exercem influência na ação do homem para o alcance de objetivos. Para aqueles empregados admitidos a 20 ( vinte), 30 ( trinta) anos atrás, a forma com a qual ingressaram na empresa, a igualdade do mercado na época, fizeram com que eles atribuíssem valor ao fato de pertenceram a empresa Atitude e aos resultados que a empresa desejava alcançar. A expressão “A gente já teve ideais, vestiu a camisa, conhecemos a história da empresa” revela um pensamento de dedicação e valorização à empresa. A autora menciona que o valor se refere ao nível de atração do trabalhador em relação aos fatores do meio ambiente, trata-se da importância que o indivíduo atribui a determinado objetivo a ser atingido. Hoje esses empregados, mesmo descontentes, não vêem que sair da empresa seja uma possibilidade atraente. Este fato é verificado com base no depoimento abaixo:

"Falta motivação nas duas categorias: novatos e antigos. A falta de motivação dever ser maior para os contratados recentemente. Pois, são pessoas que tem todo um horizonte, um universo adiante delas. A rotatividade é muito grande. Se partem para outra, é porque tem salário melhor lá fora e motivação pelo tipo de trabalho. A empresa Atitude não ofereceu condições ou de salário ou de tipo de trabalho, que prendesse este empregado aqui. Já os mais antigos estão mais comprometidos com a organização. Não existe o mesmo horizonte para ficar prestando concurso, a mesma facilidade, até por causa da idade, não dá para ficar mudando de emprego, pensando em iniciar carreira." (Entrevistado n $\left.{ }^{\circ} 1\right)$. 
Esta discrepância entre o tempo de serviços dos empregados contratados pela empresa Atitude, gerou um sentimento de rivalidade entre os empregados. De um lado, àqueles com mais tempo de serviços criticam os recém contratados porque acreditam que falta, por parte dos novatos, comprometimento com a empresa. Do outro lado, àqueles com menos tempo de casa, consideram que estão mais capacitados e que seus salários não são compatíveis com a função exercida. Evidencia-se este pensamento nas respostas abaixo:

"Maioria desmotivados, sejam os antigos ou os novatos, por motivos diferentes. Os mais antigos entraram numa época diferente, de maneira diferente, em outras circunstâncias, onde a empresa tinha outro tipo de perfil. Os novos são mais cobrados, desde a maneira do ingresso até na realização das tarefas. As pessoas que entraram antes, recebem bem na sua maioria, até mesmo pelas circunstâncias que a empresa empregou para remunerar." (Entrevistado $\left.\mathrm{n}^{\circ} 10\right)$.

“Os funcionários com mais tempo de casa são motivados porque ganham mais e, pela idade avançada, dificilmente teriam uma melhor colocação no mercado. Os funcionários com menos tempo de casa estão desmotivados porque ganham menos, e pela pouca idade, facilmente teriam uma melhor colocação no mercado. Atualmente os profissionais buscam rapidamente atingir o topo da profissão e não se acomodam no reconhecimento por tempo passado.” (Entrevistado $\left.\mathrm{n}^{\mathrm{0}} 11\right)$.

Este confronto de pensamentos entre os empregados mais antigos e os mais novos mostra um enfraquecimento das necessidades sociais da Pirâmide de Maslow. Pois, evidencia um ambiente de hostilidade, de falta de valorização verbal, de falta de comprometimento, de frustrações, de dificuldades em adaptação social.

Já há aqueles empregados que acrescentam que a desmotivação não é algo que seja possível de se mensurar de maneira geral. São fatores internos e pessoais. A transcrição abaixo, vem a confirmar o que Bergamini ( 2008) aborda, ou seja, que não há como motivar as pessoas sem considerar que elas são diferentes e qualquer gestão irá fracassar se dirigi-las como se fossem iguais. 
“As pessoas estão desmotivadas por motivos diferentes, os quais não há como identificar, diagnosticar. É muito individual o que motiva cada pessoa. Vejo vários motivos, muitos motivos em uma pessoa só. Seria impossível qualquer empresa fazer algo. Tento não vê como culpa da empresa. Uns estão desmotivados porque trabalham muito, outros porque trabalham pouco. É de pessoa para pessoa. Agora quando atribuem a desmotivação a baixa remuneração, eu abstraio este dado. Todo mundo quer ganhar mais. ”(Entrevistado $\mathrm{n}^{\mathrm{0}}$ 12).

No trecho acima, é importante ressaltar que o participante acredita que não há como identificar as causas que desmotivam o trabalhador e, com isso, promover um trabalho de motivação de cada empregado. No entanto, o estudo de Bergamini (2008) também nos mostra que a organização tem como conhecer o comportamento humano, desde que passe a adotar um enfoque descritivo, enumerativo desse comportamento.

\section{9 - Ações e omissões da empresa que desmotivam}

Em virtude das respostas e análises anteriores, comprovando que os participantes atestam que os empregados da empresa Atitude estão desmotivados, procurou-se então verificar de maneira mais objetiva quais foram as razões que levaram os empregados a se desmotivarem.

A categoria dos auxiliares descreve como principal fato que desmotiva o empregado na realização de suas tarefas a falta de critérios objetivos para a ascensão profissional. A empresa não estabelece o que cada empregado deve fazer para alcançar um percentual de gratificação mais elevado.

"Falta critérios de avaliação claros e objetivos que possibilitem melhores cargos e níveis de salários. Verifiquei que não adianta ter avaliação máxima, todos os cursos, pois alegam que não há vagas." (Entrevistado $\left.{ }^{\circ} 2\right)$. 
"Falta de objetividade das metas para alcançar um determinado nível de cargos e salários. É necessário tirar as análises subjetivas, políticas." (Entrevistado $\left.\mathrm{n}^{\mathrm{0}} 11\right)$.

“Insatisfação com o salário, a falta ou lentidão de perspectivas de progressão funcional.” (Entrevistado n $\left.{ }^{\circ} 1\right)$.

A categoria profissional dos técnicos menciona que, também em relação as gratificações, a empresa não esclarece quais são os critérios utilizados para dividir os recursos destinados a cada área.

“Distribuição desigual de recursos, de gratificações. Não há critérios de divisões.” (Entrevistado $\left.\mathrm{n}^{0} 5\right)$.

Outras observações feitas pelos participantes referem-se aos baixos salários, ao enfraquecimento das entidades, as distorções salariais entre os salários iniciais e os salários de fim de carreira, confrontando este dado com a atividade realizada e a qualificação profissional, ao choque de comportamento entre os empregados.

“A princípio pelo salário. Segundo pela falta de apoio da diretoria, que deveria se aproximar mais dos empregados, negociando novos benefícios. Também temos sindicato fraco, no qual não luta a favor dos empregados.” (Entrevistado $\left.\mathrm{n}^{\mathrm{0}} 7\right)$.

Discrepância de salários. Temos empregados antigos que recebem bem, que exercem, na maioria, atividades de gerência, que, às vezes, não desempenham as atividade condizente com o salário que recebem. De outro lado, temos empregados novos, bem capacitados e com baixa remuneração.” (Entrevistado $\left.n^{\circ} 10\right)$. 
“Os salários baixos e o choque de pensamento, de metodologia de trabalho, de comportamento profissional entre os empregados com mais tempo de serviços e os mais novos." (Entrevistado $\left.\mathrm{n}^{\circ} 8\right)$.

\subsection{0 - Necessidades de mudanças institucionais}

Para finalizar as entrevistas, foi perguntado aos participantes que descrevessem o que poderia ser feito institucionalmente para motivar as pessoas no trabalho. As respostas evidenciam a insatisfação dos empregados devido aos baixos salários, como verifica-se abaixo para um empregado do quadro de auxiliar.

“Aumentar os salários. Colocar metas junto com os empregados e remunerar por desempenho." (Entrevistado $\mathrm{n}^{0} 2$ ).

A resposta acima sugere que a empresa passe a recompensar seus empregados pelo desempenho e alcance de metas. Este mecanismo seria uma fator que motivaria os empregados a perseguir os resultados almejados pela empresa. No entanto, os prêmios ofertados vinculados ao desempenho seria uma fator externo de motivação. A Teoria da Avaliação Cognitiva menciona que quando uma recompensa externa é dada porque o indivíduo realizou uma tarefa interessante, isto pode causar queda no interesse pela tarefa e mesmo que estes prêmios sejam proporcionais ao desempenho do indivíduo, isto tenderá a diminuir a satisfação interna de realizar o trabalho.

Os empregados do quadro técnico e do quadro de analista acrescentaram que há necessidade de capacitação dos empregados (Entrevistados $n^{\circ} 8, n^{0} 12$ e n ${ }^{0} 15$ ), que a empresa tem que permitir a mobilidade entre as áreas (Entrevistados $n^{\circ} 1$ e $\left.n^{\circ} 14\right)$, acabar com práticas de protecionismo (Entrevistado $\mathrm{n}^{\circ}$ 6), promover a ascensão funcional de bons empregados por outros meios, não somente torná-los chefes ( Entrevistado $n^{\circ} 9$ ). Essas observações são consideradas por Herzberg, na Teoria dos Dois Fatores, como fatores higiênicos, pois são administradas pela empresa e estão fora do controle dos empregados, são extrínsecos ao 
indivíduo. Porém, são os principais fatores responsáveis em se evitar a insatisfação dos trabalhadores.

“ Capacitação dos quadros gerenciais, com orientação baseada na ética profissional do empregado público e noções básicas de administração, além de um estudo que possa implementar um salário compatível com o mercado." (Entrevistado $\mathrm{n}^{\circ} 8$ ).

“Capacitar as equipes e cobrar o resultado desta capacitação. Tem que reciclar. Implementar treinamentos para futuros gerentes ." (Entrevistado $\mathrm{n}^{\circ}$ 12).

"Oferecer cursos de capacitação para todos os profissionais de 6 em 6 meses, por exemplo, evitando o direcionado das escolhas. Capacitar não significa um reconhecimento, um agradecimento e sim um enriquecimento profissional.”(Entrevistado $\left.\mathrm{n}^{\mathrm{0}} 15\right)$.

“Permitir maior mobilidade, ajustar ou compatibilizar as atividades/tarefas ao perfil/temperamento de cada empregado e, pelo menos, igualar os salários aos da iniciativa privada." (Entrevistado $\mathrm{n}^{0} 1$ ).

"Permitir mobilidade entre os empregados, com concursos internos. Introduzir políticas de apoio aos empregados. Capacitar novos substitutos para os cargos de gerência. Mais reuniões dos setores ou a própria empresa como um todo, para ouvir novas idéias.” (Entrevistado $\left.n^{\circ} 14\right)$.

“Acabar com a perpetuidade no cargo. O empregado quando se torna gerente uma vez, ele é gerente a vida toda, mesmo que não ande mais desenvolvendo bem as tarefas . Não dá chance para outros profissionais." (Entrevistado $\mathrm{n}^{\circ}$ $6)$.

“Implantar mecanismo de premiações adequados para o bom técnico. Como a empresa não tem como premiar o bom técnico e, no entanto, quer mantê-lo 
na empresa, ela premia dando uma gerência. Às vezes, o profissional é bom naquilo que faz, mas não é tão bom como gerente." (Entrevistado ${ }^{\circ}$ 9).

Por fim, os empregados também identificaram que a empresa precisa implantar técnicas, que descubram qual a motivação para o trabalho de cada empregado, de maneira a individualizar o que pode levar cada indivíduo a se motivar (Entrevistado $\mathrm{n}^{0} 10$ ). A resposta abaixo, confirma as proposições de Douglas McGregor , onde ele revela que é importante que o administrador conheça a natureza do homem dentro da situação de trabalho e que se o administrador compreender seus subordinados, ele será capaz de selecionar um sistema de motivação que auxiliaria a dirigir os esforços na direção das metas desejadas.

“O órgão tem que fazer um levantamento de caráter pessoal de motivação, para identificar o que efetivamente poderia ser feito para alcançar a maior parte de anseios. Seria um levantamento de empregado por empregado. E categorizar. Não utilizar metodologia com respostas prontas, pois motivação é algo pessoal." (Entrevistado $\left.\mathrm{n}^{\mathrm{0}} 10\right)$.

Os empregados esperam que a organização promova ações motivadores voltadas para o reconhecimento de seus trabalhos. Cada participante apresenta diversas propostas que consideram como fatores motivacionais e que, caso fossem praticadas, iriam gerar reconhecimento. O reconhecimento possibilitará recompensas justas e provocará a satisfação para o trabalho. Sobre este tema, Bergamini ( 2008) explica:

\footnotetext{
As teorias da motivação consciente propõem que aquele que se engaja em determinada atividade espera ser reconhecido por seus méritos e, a partir daí, receber aquilo que percebe como recompensador, no sentido de elevar a satisfação do trabalhador quando ele se torna eficaz. Isso significa reconhecimento, independência e acesso a uma mundo melhor que possa satisfazer seu potencial criativo. ( BERGAMINI, 2008, p. 79)
}

Observa-se ainda, que a motivação para o trabalho está ligada ao cargo, às características individuais, aos resultados que o trabalho pode oferecer, ao atendimento dos objetivos ou dos desejos atuais ou futuros dos empregados, ao tempo que cada pessoa aloca para realização da tarefa, ou seja, se o trabalhador não sente o tempo passar ele está motivado em relação à atividade, agora se o dia parece longo, há falta de motivação ( BERGAMINI, 2008). 
SINTETIZAÇÃO DOS RESULTADOS

\begin{tabular}{|c|c|c|c|}
\hline \multirow[b]{2}{*}{ RESUMO DOS RESULTADOS } & \multicolumn{3}{|c|}{ CARGOS } \\
\hline & AUXILIARES & TÉCNICOS & ANALISTA \\
\hline \multirow{4}{*}{ Atividades diárias dos empregados } & Rotina excessiva & Satisfeitos com as tarefas & Gostam de ter responsabilidade \\
\hline & Excesso de trabalho & Rotina tolerável & Falta capacitação \\
\hline & Excesso de responsabilidade & Responsabilidade de acordo com o cargo & \\
\hline & $\begin{array}{l}\text { Falta de clareza nos trabalhos } \\
\text { demandados }\end{array}$ & Valorização do trabalho em equipe & \\
\hline \multirow{2}{*}{ CITAÇÕES } & $\begin{array}{l}\text { "Existe muita rotina no meu dia-a- } \\
\text { dia de trabalho. Há excesso de } \\
\text { responsabilidade na execução das } \\
\text { tarefas.” }\end{array}$ & $\begin{array}{l}\text { “...fiquei num posto que considero } \\
\text { ter as melhores tarefas a serem } \\
\text { sdesenvolvidas.” }\end{array}$ & $\begin{array}{l}\text { "O grau de responsabilidade é } \\
\text { estático, frusta a busca de maiores } \\
\text { desafios." }\end{array}$ \\
\hline & \begin{tabular}{|l|} 
“...sinto-me meio confusa na \\
finalização, por não entender bem \\
até que ponto a demanda toda é de \\
minha alçada."
\end{tabular} & $\begin{array}{l}\text { “..Em se tratando dos } \\
\text { colaboradores, eu consigo fazer } \\
\text { com que eles cumpram as tarefas, } \\
\text { além do que lhe são destinados.” }\end{array}$ & $\begin{array}{l}\text { "Há muita responsabilidade, } \\
\text { porém sinto falto de estrutura, } \\
\text { treinamento" }\end{array}$ \\
\hline \multirow{2}{*}{$\begin{array}{l}\text { Fatores que motivam que possam } \\
\text { ser promovidos pela chefia e pelo } \\
\text { próprio empregado }\end{array}$} & Diversidade nas tarefas & Desafios no trabalho & Superar expectativas \\
\hline & Reconhecimento profissional & Responsabilidade & Tarefas que trazem novidades \\
\hline \multirow{2}{*}{ CITAÇÕES } & $\begin{array}{l}\text { “...Esta ausência de variedades } \\
\text { leva a rotina e a rotina gera } \\
\text { insatisfação.”” }\end{array}$ & "O que me motiva é desafio" & $\begin{array}{l}\text { “...atender as expectativas e } \\
\text { superá-las.” }\end{array}$ \\
\hline & & $\begin{array}{l}\text { "A medida que a responsabilidade } \\
\text { vai aumentando...fico mais feliz" }\end{array}$ & \\
\hline \multirow{6}{*}{$\begin{array}{l}\text { Fatores que motivam que possam } \\
\text { ser promovidos pela organização }\end{array}$} & Promover políticas de qualidade de vida & $\begin{array}{l}\text { Introduzir critérios claros e objetivos de } \\
\text { ascensão profissional }\end{array}$ & $\begin{array}{l}\text { Coibir práticas de paternalismo, } \\
\text { favorecimento }\end{array}$ \\
\hline & $\begin{array}{l}\text { Introduzir critérios de avaliação } \\
\text { objetivos }\end{array}$ & $\begin{array}{l}\text { Introduzir políticas empresariais } \\
\text { contínuas }\end{array}$ & Permitir mobilidade \\
\hline & \begin{tabular}{|l|} 
Capacitar os gerentes com conhecimento \\
voltada o comportamento humano
\end{tabular} & $\begin{array}{l}\text { Reciclar os empregados e acabar com } \\
\text { perpetuidade dos cargos }\end{array}$ & $\begin{array}{l}\text { Promover a aproximação de } \\
\text { relacionamento entre cargos gerenciais e } \\
\text { subordinados }\end{array}$ \\
\hline & $\begin{array}{l}\text { Possibilitar um canal de comunicação } \\
\text { para se falar sobre motivação }\end{array}$ & $\begin{array}{l}\text { Capacitar os gerentes com conhecimento } \\
\text { voltada o comportamento humano }\end{array}$ & $\begin{array}{l}\text { Capacitar os gerentes com conhecimento } \\
\text { voltada o comportamento humano }\end{array}$ \\
\hline & & $\begin{array}{l}\text { Coibir práticas de paternalismo, } \\
\text { favorecimento }\end{array}$ & $\begin{array}{l}\text { Implantar mecanismos que promova } \\
\text { ascensão dentro do cargo, não somente } \\
\text { se tornando chefe }\end{array}$ \\
\hline & & $\begin{array}{l}\text { Implantar mecanismos que promova } \\
\text { ascensão dentro do cargo, não somente } \\
\text { se tornando chefe }\end{array}$ & Reciclar os cargos gerenciais \\
\hline \multirow{6}{*}{ CITAÇÕES } & $\begin{array}{l}\text { “...introduzir políticas de } \\
\text { qualidade de vida na empresa.” }\end{array}$ & $\left\{\begin{array}{l}\text { "Falta um programa com critérios, } \\
\text { orientações, nas quais a empresa } \\
\text { possa avaliar as pessoas..." }\end{array}\right.$ & $\begin{array}{l}\text { “...práticas de paternalismo, } \\
\text { nepotismo, formando uma cadeia } \\
\text { de favorecimentos mútuos” }\end{array}$ \\
\hline & $\begin{array}{l}\text { “Falta critérios de avaliação } \\
\text { claros e objetivos que possibilitem } \\
\text { melhores cargos e níveis de } \\
\text { salários. }\end{array}$ & $\begin{array}{l}\text { "Não tem um desenvolvimento } \\
\text { contínuo. Deveria ter um política } \\
\text { desencadeada." }\end{array}$ & $\mid \begin{array}{l}\text { “...Quando a organização não } \\
\text { permite essa mobilidade ela } \\
\text { promove a desmotivação.” }\end{array}$ \\
\hline & $\begin{array}{l}\text { “...chefes despreparados para } \\
\text { motivar...Não há liberdade para } \\
\text { falar sobre o tema.” }\end{array}$ & $\begin{array}{l}\text { "...Capacitar novos substitutos "“. } \\
\text { para os cargos de gerência." }\end{array}$ & $\begin{array}{l}\text { “...apoio da diretoria, que deveria } \\
\text { se aproximar mais dos } \\
\text { empregados...” }\end{array}$ \\
\hline & & $\begin{array}{l}\text { "Acabar com a perpetuidade no } \\
\text { cargo." }\end{array}$ & $\begin{array}{l}\text { Capacitação dos quadros } \\
\text { gerenciais, com orientação } \\
\text { baseada na ética profissional do } \\
\text { empregado público }\end{array}$ \\
\hline & & $\begin{array}{l}\text { "Implantar mecanismo de } \\
\text { premiações adequados para o bom } \\
\text { técnico." }\end{array}$ & \begin{tabular}{|lrr} 
“...a falta & ou & lentidão de \\
perspectivas & de & progressão \\
funcional.” & & \\
\end{tabular} \\
\hline & & $\begin{array}{l}\text { "....Só há uma maneira de crescer: } \\
\text { tem que virar chefe." }\end{array}$ & $\begin{array}{l}\text { "Tem que reciclar. Implementar } \\
\text { treinamentos para futuros } \\
\text { gerentes." }\end{array}$ \\
\hline
\end{tabular}




\section{SINTETIZAÇÃO DOS RESULTADOS}

\begin{tabular}{|c|c|c|c|c|}
\hline \multirow{2}{*}{\multicolumn{2}{|c|}{ RESUMO DOS RESULTADOS }} & \multicolumn{3}{|c|}{ CARGOS } \\
\hline & & AUXILIARES & TÉCNICOS & ANALISTA \\
\hline \multirow{5}{*}{\multicolumn{2}{|c|}{$\begin{array}{l}\text { Fatores que desmotivam existentes } \\
\text { na empresa Atitude }\end{array}$}} & $\begin{array}{l}\text { O novo plano de cargos salários não } \\
\text { trouxe benefícios salariais e progressão } \\
\text { funcional para a carreira }\end{array}$ & Falta de ascensão profissional & $\begin{array}{l}\text { Rotina desmotiva, quando a tarefa não é } \\
\text { importante }\end{array}$ \\
\hline & & $\begin{array}{l}\text { Baixos salários versus grandes } \\
\text { responsabilidades }\end{array}$ & $\begin{array}{l}\text { Ociosidade, falta de continuidade na } \\
\text { demanda das tarefas }\end{array}$ & Falta de objetividade das tarefas \\
\hline & & Falta de capacitação do corpo gerencial & Rotina, poucos desafios & $\begin{array}{l}\text { Falta de eqüidade na distribuição de } \\
\text { gratificações }\end{array}$ \\
\hline & & $\begin{array}{l}\text { Falta de comunicação entre chefia e } \\
\text { subordinados }\end{array}$ & Falta de reconhecimento & $\begin{array}{l}\text { Práticas de paternalismo, nepotismo, } \\
\text { favorecimento }\end{array}$ \\
\hline & & & Baixos salários & \\
\hline \multirow{5}{*}{\multicolumn{2}{|c|}{ CITAÇÕES }} & $\begin{array}{l}\text { “O novo plano de cargos e salários } \\
\text { não beneficiou a categoria.” }\end{array}$ & $\begin{array}{l}\text { “...falta de perspectiva de } \\
\text { ascensão profissional." }\end{array}$ & $\begin{array}{l}\text { "Rotina muito maçante } \\
\text { desmotiva." }\end{array}$ \\
\hline & & $\begin{array}{l}\text { "...responsabilidade grande e não } \\
\text { ganha por isso" }\end{array}$ & $\begin{array}{l}\text { "A ociosidade, as tarefas sazionais } \\
\text { me desmotivam" }\end{array}$ & $\begin{array}{l}\text { "Não existe uma variação de } \\
\text { atividades nas tarefas que } \\
\text { desenvolvo. Considero isso é } \\
\text { sadio, pois as tarefas são } \\
\text { importantes para o setor” }\end{array}$ \\
\hline & & $\begin{array}{l}\text { "...chefes despreparados para } \\
\text { motivar" }\end{array}$ & $\begin{array}{l}\text { "Gosto de variar, sair da rotina, } \\
\text { aprender coisas novas, novos } \\
\text { desafios." }\end{array}$ & $\begin{array}{l}\text { "...falta de objetividade } \\
\text { desmotivam o trabalho." }\end{array}$ \\
\hline & & $\begin{array}{l}\text { “...Não há liberdade para falar } \\
\text { sobre o tema." }\end{array}$ & $\begin{array}{l}\text { "...falta de reconhecimento. Não } \\
\text { cabe reclamar somente sobre a } \\
\text { questão do baixo salário." }\end{array}$ & $\begin{array}{l}\text { “...O critério de distribuição } \\
\text { financeira não é uma maneira } \\
\text { isonômica. } \\
\text { favorecimento” }\end{array}$ \\
\hline & & & $\begin{array}{l}\text { “...baixos salários, a quantidade } \\
\text { reduzida de trabalhadores, a falta } \\
\text { de realização profissional.” }\end{array}$ & \\
\hline \multirow{3}{*}{\multicolumn{2}{|c|}{$\begin{array}{l}\text { Como deve ser a gestão para que } \\
\text { ela promova motivação }\end{array}$}} & $\begin{array}{l}\text { Capacitar de acordo com a tarefa } \\
\text { realizada }\end{array}$ & $\begin{array}{l}\text { Individualizar o tratamento de seus } \\
\text { colaboradores }\end{array}$ & $\begin{array}{l}\text { Individualizar o tratamento de seus } \\
\text { colaboradores }\end{array}$ \\
\hline & & & $\begin{array}{l}\text { Deve identificar o perfil do empregado } \\
\text { para enquadrá-lo numa determinada } \\
\text { tarefa }\end{array}$ & $\begin{array}{l}\text { Repassar de forma clara e objetiva as } \\
\text { tarefas, praticar o feedback }\end{array}$ \\
\hline & & & & $\begin{array}{l}\text { Capacitar de acordo com a tarefa } \\
\text { realizada }\end{array}$ \\
\hline \multirow{2}{*}{\multicolumn{2}{|c|}{ CITAÇÕES }} & $\begin{array}{l}\text { “...Deve promover a capacitação } \\
\text { do empregado." }\end{array}$ & $\begin{array}{l}\text { "...respeitar e reconhecer o perfil } \\
\text { do subordinado, para poder } \\
\text { alocá-lo de acordo com sua } \\
\text { vocação." }\end{array}$ & $\begin{array}{l}\text { A gerência tem que identificar o } \\
\text { que significa reconhecimento para } \\
\text { cada empregado, para saber o que } \\
\text { cada um precisa para seu } \\
\text { reconhecimento. }\end{array}$ \\
\hline & & & & $\begin{array}{l}\text { “A gestão pode motivar o } \\
\text { indivíduo passando metas claras, } \\
\text { elogiando o trabalho quando é } \\
\text { feito de maneira correta e não só } \\
\text { criticando. } \\
\text { "Oferecer cursos de capacitação } \\
\text { para todos os profissionais de } 6 \\
\text { em } 6 \text { meses, por exemplo, evitando } \\
\text { o direcionado das escolhas" }\end{array}$ \\
\hline \multirow{4}{*}{$\begin{array}{l}\text { Fatores } \\
\text { neutros }\end{array}$} & Flexibilidade & $\begin{array}{l}\text { A flexibilidade não está ligada aos } \\
\text { fatores que os motivam ou desmotivam }\end{array}$ & $\begin{array}{l}\text { A flexibilidade não está ligada aos } \\
\text { fatores que os motivam ou desmotivam }\end{array}$ & $\begin{array}{l}\text { A flexibilidade não está ligada aos } \\
\text { fatores que os motivam ou desmotivam }\end{array}$ \\
\hline & CITAÇÕES & $\begin{array}{l}\text { "A falta de flexibilidade desmotiva. } \\
\text { Mas, não levo este fator em } \\
\text { consideração, pois estamos no } \\
\text { serviço publico...” }\end{array}$ & $\begin{array}{l}\text { "Não há flexibilidade na execução } \\
\text { das tarefas, porque estão } \\
\text { vinculadas à lei." }\end{array}$ & $\begin{array}{l}\text { "Entendo que flexibilidade esteja } \\
\text { associada a responsabilidade que } \\
\text { a tarefa desempenhada possui."” }\end{array}$ \\
\hline & Pressão & & Prazos & Prazos \\
\hline & CITAÇÕES & "Não há pressão..." & $\begin{array}{l}\text { “...prazo } \\
\text { pressão...prazos exigidos por lei."” }\end{array}$ & $\begin{array}{l}\text { "...pressão } \\
\text { prazos" }\end{array}$ \\
\hline
\end{tabular}

\section{5 - Conclusão}


A motivação humana tem sido alvo de estudos há algum tempo, com maior ênfase com o desenvolvimento da Teoria das Relações Humanas. Valoriza-se mais o homem como ser social e, como conseqüência, é comum vermos cada vez mais o emprego de estratégias de motivação para garantir sua realização e a concretização dos objetivos organizacionais. Hoje, os estudos ressaltam a necessidade de se conhecer o comportamento humano, os indivíduos são diferentes e requerem tratamento diferenciado. O estudo visualizou a diversificação de valor que cada participante atribui a um mesmo fator. Para uns, a motivação está fora de si e altos salários, somados aos benefícios que a empresa poderia propor, iriam gerar satisfação no trabalho. Percebe-se que a motivação está ligada a fatores coletivos. Porém, quando se aprofunda o tema, identifica-se que àquelas pessoas que consideram o salário como o principal fator de motivação, acabam enumerando vários outros fatores individuais e pessoais.

O estudo objetivou analisar se os empregados de uma Empresa Pública Federal, localizada no Distrito Federal, estão desmotivados na execução dos seu trabalhos e no alcance dos resultados organizacionais. O estudo poderá contribuir para a discussão das questões relativas ao tema motivação no trabalho, poderá tornar visível quais foram e quais são as causas que levaram e levam à desmotivação, poderá provocar uma reflexão dos seus dirigentes, em especial sobre as políticas de gestão de pessoas.

De um modo geral, pode-se afirmar que os empregados estão satisfeitos com a natureza das tarefas, que o que desmotiva não diz respeito a tarefa em si. Alguns relataram, por exemplo, que a falta de diversidade nas tarefas é desmotivante, mas que isso pode ser corrigido pelo próprio empregado. Outras respostas avaliam que ausência de diversidade não desmotiva, desde que a tarefa seja importante e com alto grau de responsabilidade. As causas, de um modo geral, estão relacionadas a outros fatores, fatores que não dependem do empregado e fatores relacionados à personalidade do empregado. São eles que levam à apatia, à frustração, ao desinteresse pelos resultados organizacionais. O estudo mostrou que se isolassem a atividade do empregado, a tarefa em si, e modificassem os demais fatores, os empregados da empresa Atitude estariam satisfeitos.

No entanto, não é possível isolar as demais causas e no decorrer das entrevistas elas surgiram evidenciando a insatisfação da grande maioria dos entrevistados. Vale ressaltar, que a análise abordou um universo de 15 ( quinze) empregados, nos três cargos profissionais existentes dentro da empresa, sejam elas: cargo de auxiliar, cargo de técnico e cargo de 
analista. Essa pequena amostra pode não evidenciar de forma ampla o contexto geral da empresa. Mas, serviu como base para mensurar alguns fatores que desmotivam.

No cargo de auxiliar, as respostas evidenciam um certo nível de frustração na natureza das tarefas. A causa desta frustração deve-se ao excesso de trabalho, rotina e falta de explicação da tarefa em si. Os argumentos verificados estão relacionados com gestão. A percepção da gestão está falha. Para os demais cargos, as tarefas estão de acordo com o esperado e responsabilidade é um fator que faz da parte da tarefa e motiva.

Quanto ao tema motivação no trabalho, o objetivo na entrevista era fazer com que os empregados respondessem quais fatores os motivam ou desmotivam ou ambas as questões. Os empregados descreveram vários fatores que motivam ou desmotivam. Os fatores mais respondidos que desmotivam são: baixos salários, ausência de um plano que possibilite progressão funcional, ociosidade, falta de cursos de capacitação, rotina, falta de isonomia na distribuição das gratificações, falta de um mecanismo que premie o bom técnico do trabalho, desassociando esta premiação do cargo de chefia. Os fatores que motivam: desafio, um grau médio para alto de responsabilidade, superação de expectativas. Neste momento, vale ressaltar dois fatores que foram tratados pelos participantes e que consideram que não influenciam o nível de motivação: pressão e flexibilidade. Por ser uma empresa pública federal, regida por leis e normas, fiscalizada pelo poder público externo, tendo como principal atividade econômica a prestação de serviços somente para órgãos públicos, os empregados atribuem que a pressão existente deve-se a observância da lei, em virtude dos prazos e das obrigações em atender o cliente, que é um ente público. Não verificaram outros tipos de pressões. Quanto a flexibilidade, ela existe nos procedimentos operacionais para execução das tarefas, mas não em relação a execução da tarefa em si. Pois, a forma de execução está descrita em lei.

Em virtude dos temas tratados acima, procurou-se obter dos participantes que eles ressaltassem até que ponto a organização é responsável, até que ponto ela provocou os fatores que desmotivam. De modo geral, as respostas dos participantes evidenciam a omissão da organização. Cabe a organização introduzir políticas voltados para o profissional e não somente políticas de alcance de resultados. A organização não pode desconsiderar os anseios de seus colaboradores. No caso da empresa Atitude, todas as respostas foram voltadas para a ação da organização, seja de introduzir políticas de qualidade de vida, de ascensão profissional, estabelecer critérios objetivos e claros de avaliação dos empregados, de mobilidade entre as áreas. Para os empregados a empresa está parada. Não constatou-se nas 
falas um movimente, por parte da empresa, de consertar, ampliar, aprofundar essa ou aquela política. As respostas estão voltadas para que a organização inicie uma ação.

Em referência a gestão dos empregados no trabalho, os participantes mensuraram a responsabilidade que a chefia imediata possui para com os seus subordinados. Identificaram que cabe à chefia entender o perfil de seus colaboradores, estabelecer uma comunicação entre a gestão e os empregados de forma clara, objetiva e ampla, buscar meios de entender o comportamento humano, para conseguir visualizar as particularidades que cada empregado possui e com isso promover a motivação.

Abordou-se também, qual a visão geral que os empregados possui sobre o tema motivação para todo o corpo funcional. Sabemos que a empresa Atitude, por ser uma empresa pública federal, está obrigada a contratar seus empregados por meio de concurso público. Esta obrigação é advinda da Constituição Federal, publicada desde 1988. A empresa somente foi contratar novos empregados cerca de 16 ( dezesseis) anos depois da publicação da CF. Esse longo espaço de tempo, gerou desequilíbrio no quadro funcional, em referência ao tempo de serviço de seus empregados. Em virtude deste desequilíbrio, o estudo mostrou uma certa rivalidade entre os dois pólos de empregados: empregados antigos, com mais de 20 ( vinte) anos de serviço, e empregados novatos, com no máximo 5 ( cinco) anos de serviço. De um lado, àqueles com mais tempo de serviços prestados criticam os recém contratados, porque acreditam que falta comprometimento com a empresa, que ao serem contratados conheciam as regras, logo não cabe reclamações a níveis salariais. Do outro lado, àqueles com menos tempo de casa consideram que estão mais capacitados e que seus salários não são compatíveis com a função exercida, que os empregados antigos ganham bem e que nem sempre estão propensos ao bom desenvolvimento das tarefas. Estes pensamentos geram um ambiente de hostilidade dentro da empresa, abalando o conceito de ética no setor público.

Em síntese, os empregados descreveram o que consideram importante para si no momento atual, sejam, por exemplo, tarefas claras e objetivas, para uns com um grau médio de responsabilidade, para outros com muita responsabilidade; tarefas importantes para a empresa; existência de desafios nas atividades; canal de comunicação aberto entre as equipes e toda a empresa; respeito pelo trabalho e/ou educação no trato das pessoas. Mencionaram o que estão vivendo na empresa e que está gerando insatisfação na atualidade. As soluções, observadas pelos participantes, iriam além de iniciativas coletivas por parte da empresa e alcançariam pequenas ações dentro das equipes. Haveria a necessidade de ter um departamento motivacional dentro de cada ambiente. Sabemos que isso é impossível. Mas o 
estudo mostrou que um passo importante da empresa amenizaria o nível de insatisfação de seus empregados: formação de líderes. Os responsáveis por outros empregados passariam a estudar o comportamento humano, para saber lidar com as diferenças. Além de bom técnico, capacitado para executar a tarefa que lhe cabe, a organização teria líderes capacitados para trabalhar em conjunto.

Portanto, o trabalho mostrou que cabe a organização iniciativas voltadas para a compreensão dos fatores que desmotivam os empregados, de maneira a individualizar os fatores internos e colocar em prática as ações que motivam externamente. É importante para o administrador conhecer as causas e os fatores que influenciam no comportamento humano, assim como suas necessidades, uma vez que a motivação é trabalhada sob esses aspectos. Este estudo vem a constatar, mais uma vez, que não existe uma fórmula ideal para se motivar pessoas. Tem que produzir técnicas de pesquisas que possam servir de base para um encaminhamento dentro da realidade da empresa. Caberá a organização desenvolver mecanismos que possam entender seus empregados, identificar fatores que possam influenciar ou interferir no comportamento de seus colaboradores, verificar o relacionamento dos empregados com a empresa, o grau de motivação de seu membros, se há algum mecanismo responsável para manter a intensidade, direção e persistência dos esforços de uma pessoa para o alcance dos resultados organizacionais. 


\section{REFERÊNCIAS}

BERGAMINI, C. W. Motivação nas Organizações. 5.ed. São Paulo: Atlas, 2008.

CHANLAT, J.F. O Gerencialismo e a ética do Bem Comum: a questão da motivação para o trabalho nos serviços públicos. 2002. Trabalho apresentado ao $7^{\circ}$ Congresso Internacional del CLAD sobre la Reforma del Estado y de la Administración Pública, Lisboa, Portugal. 2002. p. 1 - 9 .

CONNELLAN, T. K. Fator humano e desempenho empresarial. 3. ed. São Paulo: Harper \& Row do Brasil, p. 51, 1994.

FIORELLI, J. O. Psicologia para Administradores. 4. ed. São Paulo: Atlas, 2004. p. 118132.

GODOY, A. S. Introdução à Pesquisa Qualitativa e Suas Possibilidades. Revista de Administração de Empresas, São Paulo, v.35, n.3, p.20-29, mar./abr. 1995.

OLIVEIRA, M.; FREITAS, H. M. R. Focus Group - Pesquisa Qualitativa: Resgatando a Teoria, Instrumentalizando o Seu Planejamento, Revista de Administração, São Paulo, v. 33, n. 3, p. 83-91, jul./set. 1998.

RICHARDSON, R.J. et. al. Pesquisa Social: Métodos e Técnicas. 3.ed. São Paulo: Atlas, p. 207-244, 2008.

ROBBINS, S. P. Comportamento Organizacional. 9. ed. São Paulo: Prentice Hall, p. 06, p. 19-23, p. 74-78, p.151-182, 2002.

SIQUEIRA, M.M.M. Medidas do Comportamento Organizacional. Estudos de Psicologia, São Paulo, n. 7, p. 11-18, jul. 2002.

TADIN, A.P. et al. O Conceito de Motivação na Teoria de Relações Humanas. Revista de Ciências Empresariais, Paraná, v. 2, n.1, p. 40-47, jan./jun. 2005. 
VERGARA, S. C. Projetos e Relatórios de Pesquisa em Administração. 3. ed.. São Paulo: Atlas, p. 42 - 51, 2000. 